Atmos. Chem. Phys. Discuss., 11, 15075-15117, 2011

www.atmos-chem-phys-discuss.net/11/15075/2011/

doi:10.5194/acpd-11-15075-2011

(C) Author(s) 2011. CC Attribution 3.0 License.

This discussion paper is/has been under review for the journal Atmospheric Chemistry and Physics (ACP). Please refer to the corresponding final paper in ACP if available.

\title{
Impact of nitrous acid chemistry on air quality modeling results over the Pearl River Delta region
}

\section{R. Zhang ${ }^{1}$, G. Sarwar ${ }^{2}$, J. C. H. Fung ${ }^{1,3}$, A. K. H. Lau ${ }^{3}$, and Y. Zhang ${ }^{4}$}

${ }^{1}$ Department of Mathematics, The Hong Kong University of Science and Technology, Clear Water Bay, Kowloon, Hong Kong, China

${ }^{2}$ Atmospheric Modeling and Analysis Division, National Exposure Research Laboratory, Office of Research and Development, US Environmental Protection Agency, RTP, NC 27711, USA

${ }^{3}$ Division of Environment, The Hong Kong University of Science and Technology, Clear Water Bay, Kowloon, Hong Kong, China

${ }^{4}$ College of Environmental Sciences and Engineering, Peking University, Beijing, 100871, China

Received: 23 March 2011 - Accepted: 27 April 2011 - Published: 18 May 2011

Correspondence to: J. C. H. Fung (majfung@ust.hk)

Published by Copernicus Publications on behalf of the European Geosciences Union.
Impact of nitrous acid chemistry on air quality

R. Zhang et al.

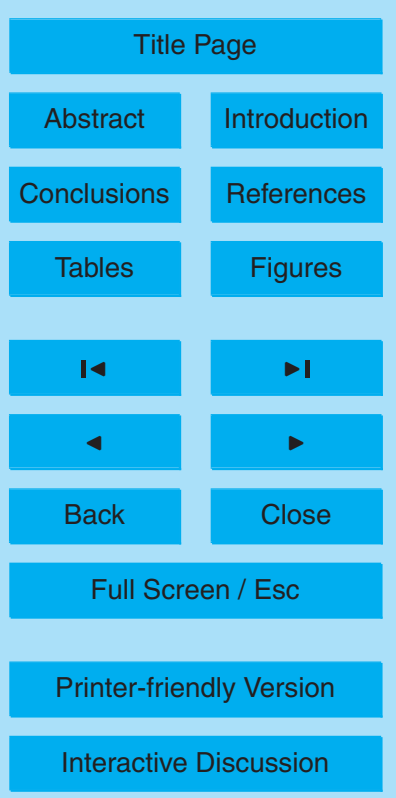




\section{Abstract}

The impact of nitrous acid chemistry on regional ozone and particulate matter in Pearl River Delta region was investigated using the Community Mutilscale Air Quality modeling system and the CB05 mechanism. Model simulations were conducted for a ten-day 5 period in October 2004. Compared with available observed data, the model performance for $\mathrm{NO}_{\mathrm{x}}, \mathrm{SO}_{2}, \mathrm{PM}_{10}$, and sulfate is reasonably good; however, predictions of HONO are an order of magnitude lower than observed data. The CB05 mechanism contains several homogenous reactions related to nitrous acid. To improve the model performance for nitrous acid, direct emissions, two heterogeneous reactions, and two surface photolysis reactions were incorporated into the model. The inclusion of the additional formation pathways significantly improved simulated nitrous acid compared with observed data. The addition of nitrous acid sources enhance daily maximum 8-h ozone by up to $6 \mathrm{ppb} \mathrm{V}(8 \%)$ and daily mean $\mathrm{PM}_{2.5}$ by up to $17 \mu \mathrm{g} \mathrm{m}^{-3}(12 \%)$. They also affected ozone control strategy in Pearl River Delta region.

\section{Introduction}

The importance of nitrous acid (HONO) to tropospheric chemistry is well recognized due to its contribution to $\mathrm{HO}_{x}\left(\mathrm{OH}+\mathrm{HO}_{2}\right)$ budget, which may lead to the enhancement of overall oxidation capacity of the atmosphere (e.g., Harris et al., 1982; Jenkin et al., 1988; Staffelbach et al., 1997; Winer and Biermann, 1994; Alicke et al., 2002, 2003;

Acker et al., 2006). Accumulated HONO at night would undergo photolysis after sunrise to become an important source of hydroxyl radical $(\mathrm{OH})$. It is especially important in the early morning when other major $\mathrm{OH}$ sources (e.g. the photolysis of ozone $\left(\mathrm{O}_{3}\right)$ ) are still small.

$\mathrm{HONO}+h v(300 \mathrm{~nm}<\lambda<400 \mathrm{~nm}) \rightarrow \mathrm{OH}+\mathrm{NO}$

\section{Impact of nitrous acid chemistry on air quality}

R. Zhang et al.

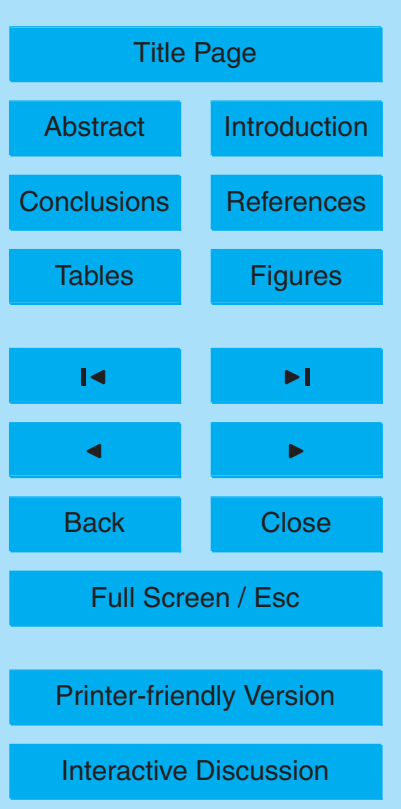


Analysis of measured HONO in urban area of Europe suggested that Reaction (R1) contributes more than $30 \%$ of the integrated photolytic $\mathrm{HO}_{x}$ formation (Alicke et al., 2003; Acker et al., 2006). Some recent studies even suggested that Reaction (R1) may be significant not only in the early morning but also through the entire day especially 5 over the remote environment (Kleffmann et al., 2005; Ren et al., 2006; Elshorbany et al., 2009; Mao et al., 2010). Box model studies also corroborated the importance of $\mathrm{HONO}$ photolysis to $\mathrm{HO}_{\mathrm{x}}$ budget and further quantified its impact on $\mathrm{O}_{3}$ build-up. For example, Harris et al. (1982) reported that at most $44 \%$ increase of daily $\mathrm{O}_{3}$ level occurred by assuming the initial mixing ratio of $\mathrm{NO}_{\mathrm{x}}$ and $\mathrm{HONO}$ as $120 \mathrm{ppb} \mathrm{V}$ (Part 10 per Billion by Volume) and $10 \mathrm{ppb} \mathrm{V}$ in box model calculation. Jenkin et al. (1998) considered an injection of $1 \mathrm{ppb} \mathrm{V}$ HONO in a 1-D box model and reported that $\mathrm{OH}$ mixing ratio increased 5 times in the morning and $14 \%$ at noon, which subsequently enhanced $\mathrm{O}_{3}$ production efficiency by $16 \%$ and maximum $\mathrm{O}_{3}$ mixing ratio by $8 \%$.

Despite the importance of HONO to tropospheric chemistry, the detail formation mechanisms, especially during daytime, have not been well established yet and incorporated into air quality models. To date, there are two review papers by Calvert et al. (1994) and Kelffmann (2007) to summarize the current knowledge on HONO formation mechanisms. Four groups of HONO formation pathways were identified: direct emission, homogeneous reactions, heterogeneous reactions and surface photolysis reactions.

\subsection{Direct emission}

HONO can be directly emitted into the atmosphere via combustion process (e.g. vehicle exhaust) when temperature of produced NO (from nitrogen thermal fixation) is decreased (Calvert et al., 1994). Measurements of HONO emission from combustion system are mainly focused on motor vehicles, especially diesel vehicles. Kessler and Platt (1984) indicated that $\mathrm{HONO} / \mathrm{NO}_{\mathrm{x}}$ emission ratio from engines without catalytic converters in Germany are smaller than $0.15 \%$ while the ratio for diesel engines is around $1 \%$. Kurtenbach et al. (2001) reported $\mathrm{HONO} / \mathrm{NO}_{\mathrm{x}}$ emission ratios from

\section{Impact of nitrous acid chemistry on air quality \\ R. Zhang et al.}

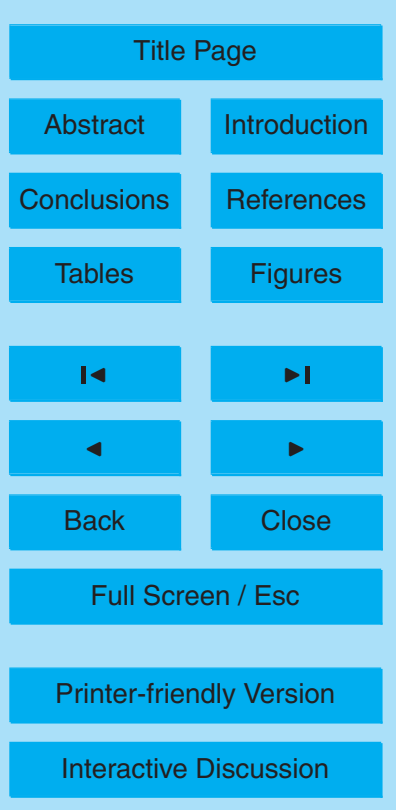


truck, diesel engine powered car, and gasoline engine powered cars are $0.8 \%, 0.66 \%$ and $0.53 \%$, respectively. Tunnel studies by considering fleet composition and engine technology showed that on average $0.3 \sim 0.8 \%$ of total traffic induced $\mathrm{NO}_{\mathrm{x}}$ can be apportioned to direct HONO emission (Kirchstetter and Littlejohn, 1996; Ackermann, 5 2000). Direct HONO emission source can possibly play an important role over heavily polluted areas with high traffic volume.

\subsection{Homogenous reaction}

The most important homogeneous reaction that produces HONO is the reverse reaction of Reaction (R1) (Kelffmann, 2007):

$\mathrm{OH}+\mathrm{NO}+\mathrm{M} \rightarrow \mathrm{HONO}+\mathrm{M}$

This reaction has a greater role during daytime when the mixing ratios of $\mathrm{OH}$ and $\mathrm{NO}$ are high and little contribution to the HONO build up at night. Alicke et al. (2002) pointed out that mixing ratio of HONO around noon generated by Reaction (R2) is only in the range of several pptVs over urban areas, which cannot explain the observed daytime high level. Another homogenous reaction that can produce HONO in urban areas is the excited $\mathrm{NO}_{2}\left(\mathrm{NO}_{2} \mathrm{E}\right)$ chemistry (Li et al., 2008). $\mathrm{NO}_{2} \mathrm{E}$ can be formed via photoexcitation of $\mathrm{NO}_{2}$ by visible light (Li et al., 2008). Sarwar et al. (2010) evaluated impact of the excited $\mathrm{NO}_{2}$ chemistry on air quality and reported that it has a relatively small impact on $\mathrm{O}_{3}$ and $\mathrm{HONO}$ in the current US atmosphere.

Homogeneous reaction involving $\mathrm{NO}, \mathrm{NO}_{2}$, and $\mathrm{H}_{2} \mathrm{O}$ can also produce $\mathrm{HONO}$ in the atmosphere; their contribution is generally small. For example, the Carbon Bond 2005 (CB05) chemical mechanism contains such reaction (Yarwood et al., 2005):

$\mathrm{NO}+\mathrm{NO}_{2}+\mathrm{H}_{2} \mathrm{O} \rightarrow 2.0 \mathrm{HONO}$

\section{Impact of nitrous acid chemistry on air quality}

R. Zhang et al.

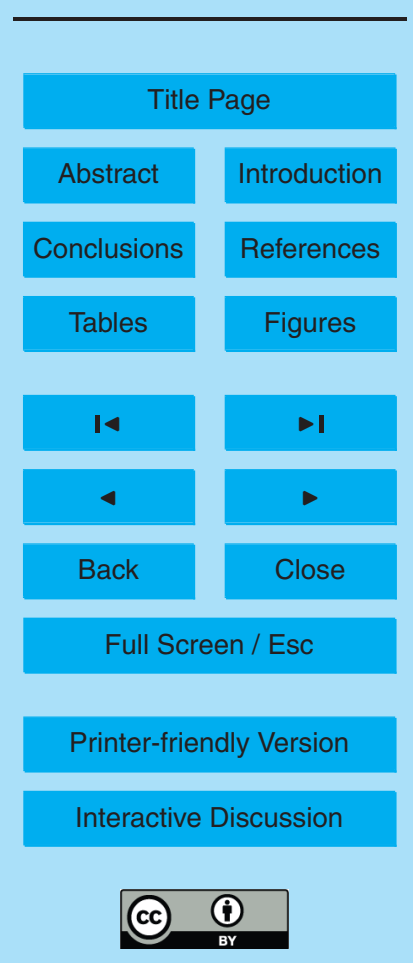


Besides Reaction (R1), HONO can undergo additional reactions. For example, the CB05 chemical mechanism contains two other homogeneous reactions related to HONO (Yarwood et al., 2005); however their impacts are likely to be small.

$\mathrm{HONO}+\mathrm{HONO} \rightarrow \mathrm{NO}+\mathrm{NO}_{2}+\mathrm{H}_{2} \mathrm{O}$

$\mathrm{OH}+\mathrm{HONO} \rightarrow \mathrm{NO}_{2}+\mathrm{H}_{2} \mathrm{O}$

\subsection{Heterogeneous reactions}

Most chamber studies indicated the importance of HONO production through the heterogeneous conversion of $\mathrm{NO}_{2}$ absorbed on the available surfaces in the presence of water vapor (Svensson et al., 1987; Calvert et al., 1994).

$\mathrm{NO}+\mathrm{NO}_{2}+\mathrm{H}_{2} \mathrm{O}$ (surface) $\rightarrow 2 \mathrm{HONO}$

$\mathrm{NO}_{2}+\mathrm{H}_{2} \mathrm{O}$ (surface) $\rightarrow \mathrm{HONO}+\mathrm{HNO}_{3}$

Reported rate constant of Reaction (R7) differ by two orders of magnitude (Cai, 2005 and the references therein) and is quite uncertain. Kleffmann et al. (1998) suggested that Reaction (R7) is not a significant contributor to HONO. The reaction rate $k_{\mathrm{HONO}}$ 5 for Reaction (R8) is believed to be first order in $\mathrm{NO}_{2}$ (Kelffmann et al., 1998; Svensson et al., 1987; Aumount et al., 2003). Furthermore, $k_{\text {HONO }}$ is not only dependent on the abundance of surface to volume ratio $(S / \mathrm{V})$ but also on ambient relative humidity $(\mathrm{RH})$ (Stutz et al., 2004). The "surface" in Reaction (R8) may represent aerosol surface as well as ground surface including soil, buildings and vegetations. The heterogeneous increase of $S / V$ ratio and the strong dependence on surface properties.

While Ammann et al. (1998) and Gutzwiller et al. (2002) suggested that Reaction (R9) can produce HONO on organic surfaces, Kleffmann et al. (1999) and Arens et al. (2001) suggested that surface deactivation occurs within a few minutes and con15 sequently Reaction (R9) is not an important pathway for HONO production in the atmosphere.

$\mathrm{NO}_{2}+$ reduced surface $\rightarrow \mathrm{HONO}+$ oxidized surface 15079
$11,15075-15117,2011$

\section{Impact of nitrous acid chemistry on air quality}

R. Zhang et al.

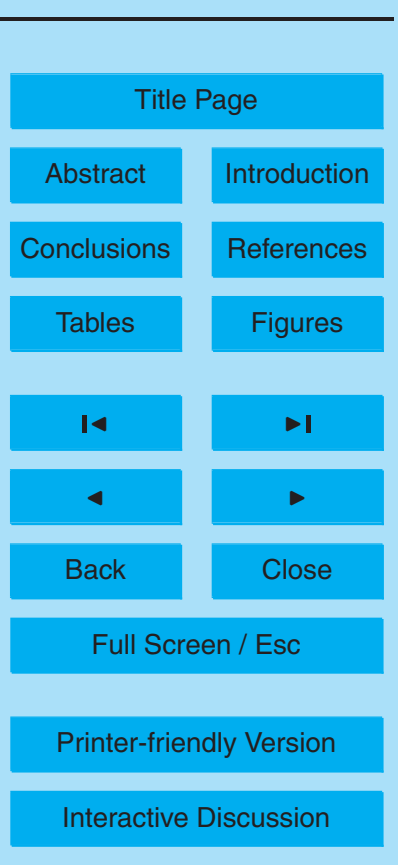


Rivera-Figueroa et al. (2003) proposed renoxification of $\mathrm{HNO}_{3}$ on the surfaces within the boundary layer of polluted atmosphere:

$\mathrm{NO}+\mathrm{HNO}_{3}$ (surface) $\rightarrow \mathrm{NO}_{2}+\mathrm{HONO}$

The "surface" in Reaction (R10) may represent ground surface including soil, build5 ings and vegetations. Given the abundant available reaction surface present (e.g. high density urban area), Reaction (R10) would lead to the generation of additional $\mathrm{NO}_{\mathrm{x}}$ in the range of tens of ppbs, hence has the potential to solve the discrepancy between observation and simulation in $\mathrm{O}_{3}$ mixing ratio (Knipping and Dabdub, 2002).

\subsection{Surface photolysis}

10 With the involvement of solar radiation, two pathways are believed to be important source for daytime HONO formation. The first pathway is the photosensitized reduction of $\mathrm{NO}_{2}$ on organic surface (Stemmler et al., 2006, 2007).

$\mathrm{NO}_{2}+A_{\text {red }}($ surface $)+h v \rightarrow \mathrm{HONO}+A^{\prime \prime}$

where $A_{\text {red }}$ is the reduced photosensitizer in aromatic hydrocarbons or humid acids.

The second pathway is the photolysis of absorbed of nitric acid $\left(\mathrm{HNO}_{3}\right)$ deposited on the ground (Zhou et al., 2002; Ramazan et al., 2004).

$\mathrm{HNO}_{3}+h v \rightarrow 0.5 \mathrm{HONO}+0.5 \mathrm{NO}_{2}$

\subsection{Modeling attempts for HONO production}

Aumont et al. (2003) studied the impact of direct HONO emissions and heterogeneous reactions producing $\mathrm{HONO}$ on aerosols and ground surfaces by using a two-layer boxmodel. The removal of $\mathrm{NO}_{2}$ by dry deposition was assumed to be linked to HONO production at ground surfaces. The rate constant for the heterogeneous reaction on ground surfaces was estimated as $0.5 \times$ deposition velocity/mixing height. They reported that the impact of the HONO sources enhanced in polluted conditions. Vogel 15080

$11,15075-15117,2011$

\section{Impact of nitrous acid chemistry on air quality}

R. Zhang et al.

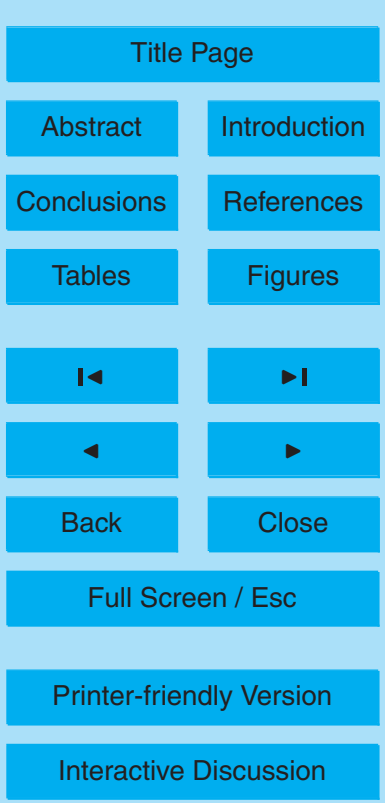

Interactive Discussion 
et al. (2003) studied the impact of various HONO sources at a site in Germany by using a one dimensional air quality model and reported that heterogeneous reactions at ground (Reaction R8) and emissions were the most important sources of night time HONO. However, the model failed to capture the production of daytime HONO. The 5 model predictions of daytime HONO improved when they added an artificial daytime HONO source.

Attempts to study HONO chemistry in 3-D air quality model are quite limited due to the relative complexity for model incorporation and large uncertainty for relative parameter estimation. Lei et al. (2004) studied the impact of HONO produced by the 10 heterogeneous conversion of $\mathrm{NO}_{2}$ on soot aerosol surfaces (Reaction R8) using a 3-D chemical transport model in Houston. They used a higher uptake coefficient for the heterogeneous reaction as reported by Amman et al. (1998) and scaled modeled soot aerosols to convert simulated mixing ratios similar to those observed in Houston area. Using these values, they reported that HONO produced by the heterogeneous reaction enhanced daytime $\mathrm{OH}$ and subsequently increased morning as well as daytime $\mathrm{O}_{3}$. Morning $\mathrm{O}_{3}$ increased by $1 \mathrm{ppb} \mathrm{V}$ and daytime $\mathrm{O}_{3}$ increase increased by $4-12 \mathrm{ppb} \mathrm{V}$. As mentioned earlier, numerous studies suggested that surface deactivation occurs quickly; thus effective uptake coefficient of Reaction (R9) is smaller and it cannot account for observed elevated HONO in the atmosphere (Kleffmann et al., 1999; Arens 20 et al., 2001).

Sarwar et al. (2008) added heterogeneous Reaction (R8), surface photolysis Reaction (R12) as well as direct HONO emission into Community Multiscale Air Quality (CMAQ) model and performed air quality model simulation with the CB05 chemical mechanism for the Eastern US. Simulation results were compared with HONO measurements from the 2001 Northeast Oxidant and Particle study. Sixty percent $(60 \%)$ of observed mean HONO was reproduced with the additional HONO formation pathways whereas the CMAQ model with just CB05 mechanism could only explain $2 \%$ of the observed value. Model predictions suggested that the heterogeneous pathway was the most significant source of $\mathrm{HONO}$ at night, while the photolysis pathway was the most

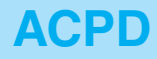

$11,15075-15117,2011$

\section{Impact of nitrous acid chemistry on air quality \\ R. Zhang et al.}

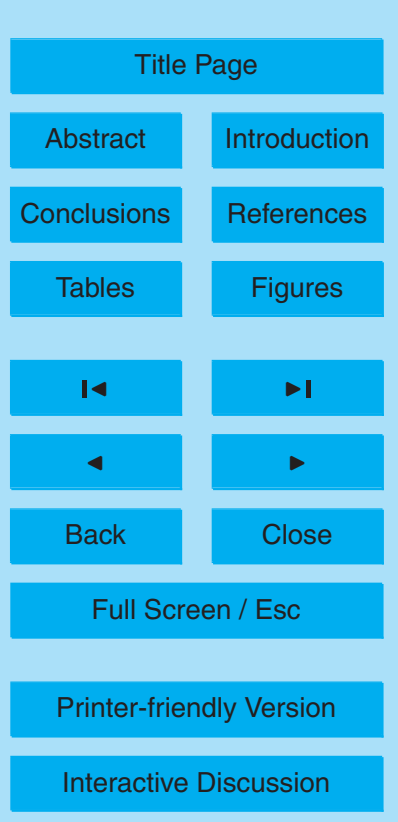


significant source during the day. The addition of these sources increased diurnally averaged $\mathrm{OH}$ radical and $\mathrm{O}_{3}$ by $10 \%$ and $1.4 \mathrm{ppb}$ V, respectively. Sarwar et al. (2008) also implemented the production of $\mathrm{HONO}$ via heterogeneous reaction at ground using procedure described by Aumont et al. (2003). Predicted nighttime HONO was lower 5 than the value obtained with the method described in Sarwat et al. (2008) and lower than the observed data by a factor of 2 .

Li et al. (2010) recently investigated the contribution of HONO sources to photochemistry in Mexico City during the MCMA-2006/MILAGO Campaign using WRF-CHEM model with SAPRC99 gas phase chemical mechanism. They parameterized the sec10 ondary $\mathrm{HONO}$ formation from $\mathrm{NO}_{2}$ heterogeneous reaction with semivolatile organics, $\mathrm{NO}_{2}$ reaction with freshly emitted soot, $\mathrm{NO}_{2}$ heterogeneous reaction on aerosol and ground surfaces. They used procedures described by Aumont et al. (2003) to model HONO formation at ground surfaces. Since surface deactivation occurs quickly, heterogeneous reaction on only fresh soot aerosols was considered. The additional HONO 15 Sources can significantly improve $\mathrm{HO}_{\mathrm{x}}$ simulations during daytime and the partition of $\mathrm{NO} / \mathrm{NO}_{2}$ in the morning. Noticeable enhancement of $\mathrm{O}_{3}$ mixing ratio $(6 \mathrm{ppb} \mathrm{V}$ for midday average), particle-phase nitrate and ammonium mixing ratios, as well as secondary organic aerosol mixing ratios were found especially in the early morning. HONO formation on semi-volatile organics was the most significant contributor and accounted 20 for $75 \%$ of predicted HONO. Reaction on ground surfaces was also important and accounted for $18 \%$ of predicted HONO. However, heterogeneous reaction on freshly emitted soot aerosols (Reaction R9) was found to be insignificant.

Limited measurements in PRD region indicate the presence of elevated ambient $\mathrm{HONO}$ levels in urban as well as rural areas. For example, early-morning HONO mixing ratio of up to $12 \mathrm{ppb} V$ was measured at Guangzhou (GZ) in June 2000 (Hu et al., 2002). Mean noon value of about $4 \mathrm{ppbV}$ at $\mathrm{GZ}$ was measured during the first Program of Regional Integrated Experiments on air quality over the PRD in October 2004 (PRIDEPRD2004, Zhang et al., 2008a). A nocturnal peak HONO mixing ratio of over $8 \mathrm{ppb} \mathrm{V}$ was reported in PRIDE-PRD2006 campaign (Qin et al., 2009). High nighttime HONO

\section{Impact of nitrous acid chemistry on air quality \\ R. Zhang et al.}

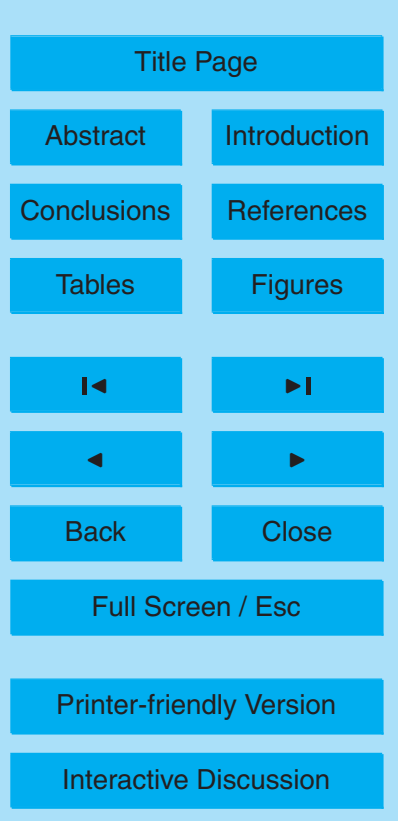

Interactive Discussion 
levels of up to $4 \mathrm{ppbV}$ (Su et al., 2008) occurred even at the rural site Xinken (XK), which is located at western coast of Pearl River Estuary (PRE) (see Fig. 1).

Observation based model (OBM) also supported the importance of HONO chemistry to the PRD region especially during the episode days. Zhang et al. (2008b) 5 used the observed HONO data at XK as input to GIT-OBM model and compared simulation results to those obtained with gas-phase HONO chemistry only. Two to four times increase of $\mathrm{OH}$ and $\mathrm{O}_{3}$-to-NO production rate were found both at $\mathrm{GZ}$ or $\mathrm{XK}$ site, which may suggest the importance of heterogeneous reactions of HONO to regional photochemical process. Lu et al. (2010) employed the same model to investigate the 10 importance of HONO during the PRIDE_PRD2006 campaign. It was suggested that it is one of the critical species for radical recycling and photochemical $\mathrm{O}_{3}$ production for the urban areas.

In this study, direct HONO emissions and four additional HONO formation pathways are incorporated into $\mathrm{CMAQ}$ model and their effects on predicted $\mathrm{HONO}, \mathrm{O}_{3}$, and par15 ticulate matter (PM) are investigated.

\section{Methodology}

\subsection{Model description}

CMAQ version 4.6 was used for this study (Byun and Schere, 2006). Modeling domain was shown in Fig. 1 and consisted of $49 \times 49$ grid-cells with $4.5 \mathrm{~km}$ grid spacing. 20 The boundary conditions of the domain of interest were provided by the outer nesting domains and kept consistent for different case run. Twenty vertical layers were constructed in CMAQ with the first layer around $17 \mathrm{~m}$ above the ground and 11 vertical layers below $1 \mathrm{~km}$. The CB05 gas-phase chemical mechanism (Yarwood et al., 2005) was used. The calculation of convective cloud mixing in the planetary boundary layer was represented by Asymmetric Convection Model (ACM, Pleim and Chang, 1992). The aerosol process was represented by fourth generation CMAQ aerosol

\section{Impact of nitrous acid chemistry on air quality \\ R. Zhang et al.}

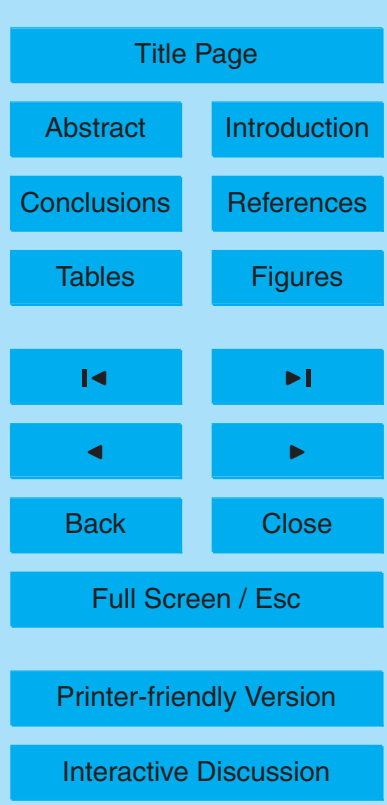


module (AERO4), which includes SORGAM (Schell et al., 2001) as a secondary organic aerosol model, ISORROPIA (Nenes et al., 1998) as an inorganic aerosol model, and RPM (Binkowski and Roselle, 2003) as a regional particulate model. Boundary conditions for the model were generated from the CMAQ results of larger domain cov5 ering the Southern China. Initial conditions for the model were chosen from default mixing ratio profiles and the first 3 day of simulation was used as model spin-up.

The meteorological field for the CMAQ model was simulated by the Fifth-Generation National Center of Atmospheric Research/Pennsylvania State University (NCAR/PSU) Mesoscale Model (MM5) version 3.6.3 (Grell et al., 1999) with updated land use infor10 mation and four dimensional data assimilation (FDDA). Detail descriptions on model configuration and data pre-processing can be found in Yim et al. (2007). Pervious comprehensive model performance evaluations by comparing the modeled pressure, ground temperature, wind speed, wind direction, $\mathrm{RH}$ with available global telecommunication system observations had demonstrated that this set of MM5 simulation can 15 represent the regional flow pattern reasonably well (e.g., Lo et al., 2006; Yim et al., 2007; Lu et al., 2009) and is suitable for driving chemical transport model for regional air quality study (Huang, et al., 2005; Kwok et al., 2010).

\subsection{Emissions for the model}

PRD local emission inventory developed by "bottom-up" methods were allocated into 20 domain grids by Sparse Matrix Operator Kernel Emissions (SMOKE v2.1, Houyoux and Vukovich, 1999) through spatial surrogate file, temporal profiles and chemical speciation profiles (CH2M Hill, 2002). Due to lack of systematic work on local PM and VOC speciation profiles for different sources in China (Street et al., 2003), the corresponding SPECIATE algorithm (USEPA, 2000) was introduced to apportion VOC to the Biogenic Emission Inventory System, version 2 (BEIS2) with emission factors and the land cover information provided by the Hong Kong Planning Department (Kwok et al., 2009).

\section{Impact of nitrous acid chemistry on air quality \\ R. Zhang et al.}

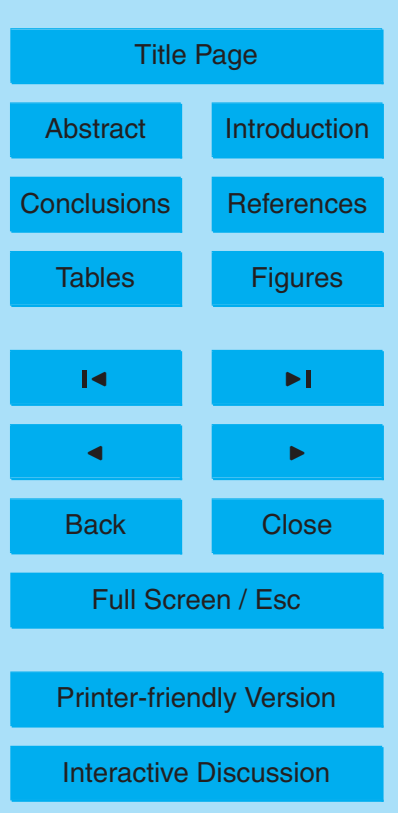




\subsection{HONO formation pathways}

The CB05 gas-phase chemical mechanism in CMAQ model contains known homogeneous reactions involving $\mathrm{HONO}$ except the excited $\mathrm{NO}_{2}$ chemistry (Reaction $\mathrm{R} 3$ ) which is not included in this study since Sarwar et al. (2010) reported that it contributes only a small amount to daytime HONO. CMAQ version 4.6 does not contain any direct $\mathrm{HONO}$ emissions from vehicles. In this study, direct $\mathrm{HONO}$ emissions are also included. Three groups of additional HONO formation pathways as described earlier were incorporated into CMAQ model. Compared to the similar study of Sarwar et al. (2008), Reactions (R11) and (R12) are the first time to incorporate into a 3-D air quality 10 model for quantifying the HONO impact on air quality modeling results.

Direct HONO emission over PRD region is estimated from on-road and off-road vehicle sources as a fraction of $\mathrm{NO}_{\mathrm{x}}$ vehicle emission; $\mathrm{HONO} / \mathrm{NO}_{\mathrm{x}}$ emission ratio is set to 0.008 based on the results report by Kurtenbach et al. (2001). Vehicle $\mathrm{NO}_{\mathrm{x}}$ emission was initially speciated into $\mathrm{NO}$ by $90 \%$ and $\mathrm{NO}_{2}$ by $10 \%$ (by volume). For this study, 15 we modified the speciation of vehicle $\mathrm{NO}_{\mathrm{x}}$ emission into $\mathrm{NO}$ by $90 \%, \mathrm{NO}_{2}$ by $9.2 \%$, and $\mathrm{HONO}$ by $0.8 \%$. Su et al. (2008) reported an upper limit of 0.01 for $[\mathrm{HONO}] /\left[\mathrm{NO}_{x}\right]$ ratio in PRD, which is consistent with the value used in this study.

$\mathrm{HONO}=0.008 \times \mathrm{NO}_{\mathrm{x}}$

Estimates of direct HONO and other emissions were developed using the Sparse Matrix Operator Kernel Emission (SMOKE) (Houyoux et al., 2000). The spatial distribution as well as temporal profile of ground HONO emission rate is demonstrated in Fig. 2. The general HONO distribution pattern matches with PRD road network and the emission rate is scaled by total vehicle volume. Multiple hotspots with the average daily emission rate greater than 0.5 molec s$^{-1}$ are found at GZ city and its vicinity area, Dongguan and Shenzhen city cluster and Central in Hong Kong. The emission gradient between eastern and western part of PRE is noticeable. The diurnal variation of HONO emission rate closely follows the vehicle use pattern. Emission rates are relatively high

\section{Impact of nitrous acid chemistry on air quality \\ R. Zhang et al.}

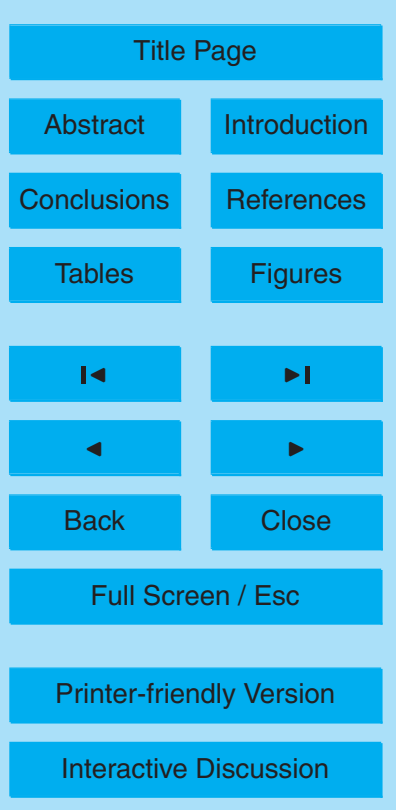


during daytime (08:00-19:00 LST), then drop after the midnight (00:00 LST), and increase again around 07:00 LST with the start of morning rush hour.

Two heterogeneous Reactions (R8) and (R10) were added to the CMAQ model. The first order reaction constant $k_{\mathrm{HONO}}$ is given as:

$5 \quad k_{\mathrm{HONO}}=\frac{\gamma_{\mathrm{rxn}} \times[S / V] \times \omega}{4}$

where $\gamma_{\mathrm{rxn}}$ is dimensionless reactive uptake coefficient. The $\gamma_{\mathrm{rxn}}$ for Reaction (R8) is taken as $1.0 \times 10^{-6}$ (Aumont et al., 2003) and for Reaction (R10) is taken as $1.0 \times 10^{-8}$ as (Rivera-Figueroa et al., 2003), $\omega$ is mean thermal velocity of given reactant and is calculated following Pleim et al. (1995).

The estimation of $S / V$ for heterogeneous reactions is a challenging task. Total $S / V$ ratio for Reaction (R8) includes model resolved aerosol surface area and other available surface area at the first model layer:

$$
\begin{aligned}
{[S / V]_{\text {surface }} } & =[S / V]_{\text {aerosol }}+[S / V]_{\text {ground }} \\
& =[S / V]_{\text {aerosol }}+\left(2 \times \mathrm{LAl} / z_{S}+[S / V]_{\text {building }}+[S / V]_{\text {soil }}\right)
\end{aligned}
$$

15 Here, $S / V$ for building is taken to represent surface areas provided by buildings, roads, parking lots, and other structures. Unless during heavily polluted days, the $S / V$ ratio for aerosol is much smaller than corresponding $S / V$ values for available surface on the ground (Sarwar et al., 2008). $S / V$ ratio for vegetation can be represented by leaf area index (LAI) in the first model layer $z_{\mathrm{s}}$. The LAl values were multiplied by two to account for both sides of leaves into total reaction interface (Jones, 2006). The $S / V$ ratio for soil is set to $0.1 \mathrm{~m}^{-1}$. Svensson et al. (1987) studied the kinetics of the reaction involving $\mathrm{NO}_{2}$ and $\mathrm{H}_{2} \mathrm{O}$ and suggested a $S / V$ value of $0.2 \mathrm{~m}^{-1}$ for typical urban environment. However, Cai (2005) used a value of $1.0 \mathrm{~m}^{-1}$ to represent the high urban density environment in New York. In this study, the estimated $S / V$ ratio for building at each grid is taken as proportional to the model resolved urban fraction (PURB, with the range $10 \%$ to $100 \%$, see Fig. 1 ) and capped with an empirical upper limit $s_{\max }$. Over 15086

\section{Impact of nitrous acid chemistry on air quality}

R. Zhang et al.

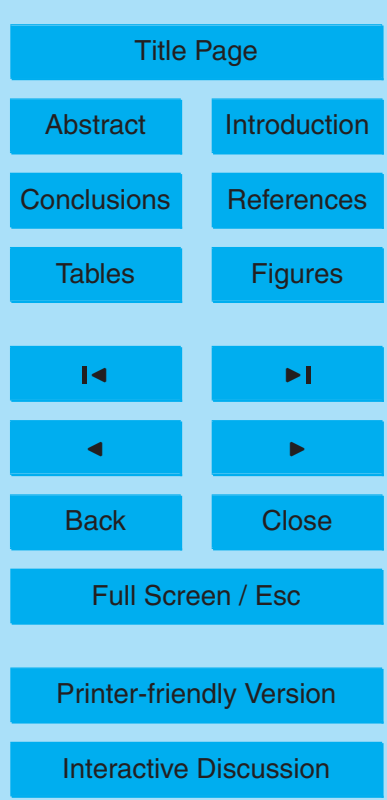


the very low urban density place with PURB less than $10 \%, S / V$ for building is a fixed value as $10 \%$ of $s_{\max }$ :

$[S / V]_{\text {building }}= \begin{cases}s_{\max } \times 10 / 100=s_{\max } / 10 & \text { if PURB }<10 \% \\ s_{\max } \times \mathrm{PURB} / 100 & \text { if } 10 \%<\mathrm{PURB}<100 \%\end{cases}$

where $s_{\max }=0.3 \mathrm{~m}^{-1}$ is used for the base case following Sarwar et al. (2008). Sensitivity study is also conducted to investigate the impact of alternative value of Smax on predicted HONO. Values of $S / V$ for building over water were set to zero. In the model, Reaction (R9) can produce HONO on aerosol surfaces at all vertical levels while it can only produce HONO in the first layer on ground surfaces.

For renoxification of nitric acid (Reaction R10), only the $S / V$ on the ground surface 10 is considered. In the model, production of HONO from Reaction (R10) can only occur in the first layer.

Two surface photolysis pathways (Reactions R11 and R12) for HONO formation are added into CMAQ to investigate the production of HONO during daytime. As regard to the photosensitized reduction of $\mathrm{NO}_{2}$ on humic acid coated aerosol (R11), 15 HONO-production is not linearly increased with the integrated actinic flux $F$ (photons $\mathrm{m}^{-2} \mathrm{~s}^{-1}, 300-750 \mathrm{~nm}$ ) due to the quick deactivation process by reaction with photo-oxidants which are formed simultaneously during the irradiation of humic acid surfaces (Stemmler et al., 2006). In this study, the empirical first order HONO formation model suggested by Stemmeler et al. (2007) is parameterized into CMAQ with the uptake coefficient $\left.\gamma_{r \times n}\right|_{\mathrm{HA}}$.

$$
\left.\gamma_{r \times n}\right|_{\mathrm{HA}}=\frac{4}{\omega} \times \frac{1}{9.3 \times 10^{22} \times\left[\mathrm{NO}_{2}\right] \times[F]^{-1}+2330}
$$

where mixing ratios of $\mathrm{NO}_{2}$ is in $\mathrm{ppb}$. Only the $S / V$ ratio for soil is considered for Reaction (R11). In the model, HONO production from Reaction (R11) is released in the first layer only.

\section{Impact of nitrous acid chemistry on air quality}

R. Zhang et al.

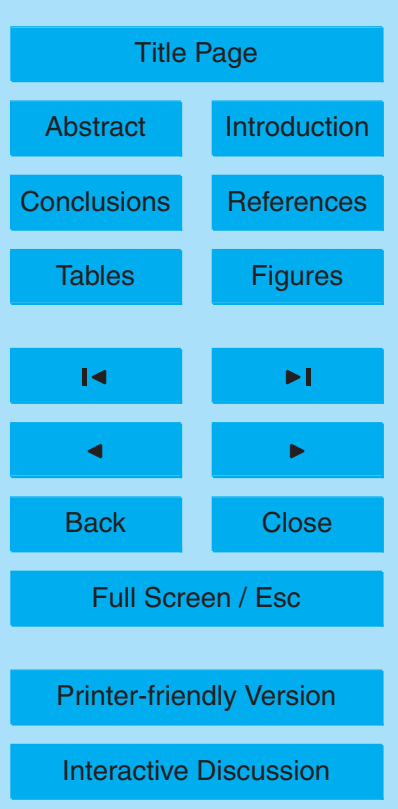


$\mathrm{HONO}$ formation through photolysis of absorbed $\mathrm{HNO}_{3}$ on surfaces (Reaction R12) was incorporated into the model upon the empirical relationship derived from laboratory measurements (Zhou et al., 2003):

$\mathrm{d}[\mathrm{HONO}] / \mathrm{d} t=\left\{\alpha \times J_{\mathrm{HNO}_{3}}^{*} \times V_{\mathrm{d}_{\mathrm{HNO}}} \times\left[\mathrm{HNO}_{3}\right] \times \Delta t\right\} / z_{\mathrm{S}}$

5 where, $\alpha$ is the fraction of deposited $\mathrm{HNO}_{3}$ exposure to full noontime sunlight with the photolysis rate $\mathrm{JHNO}_{3}$. In this study, $\alpha$ is set as $0.5 .\left.V_{\mathrm{d}}\right|_{\mathrm{HNO}_{3}}$ is dry deposition velocity of $\mathrm{HNO}_{3},\left[\mathrm{HNO}_{3}\right]$ is the mixing ratio in the first model layer, $\Delta t$ is accumulated time since the last precipitation event. The model assumes the wet deposition removes all absorbed $\mathrm{HNO}_{3}$ on the ground and resets it to zero for subsequent simulation. The 10 photolysis rate of adsorbed $\mathrm{HNO}_{3}$ reported by Zhou et al. (2003) is 24 times greater than the photolysis rate of gaseous $\mathrm{HNO}_{3}$; thus it was taken as $J_{\mathrm{HNO}_{3}}^{*}=24 \times \mathrm{J}_{\mathrm{HNO}_{3}}$ in the model, HONO production from Reaction (R12) is released in the first layer only.

\subsection{General synoptic condition and case selection}

The time period for HONO simulation over PRD region is chosen from 23 October 2004 15 to 2 November 2004, when the PRIDE-PRD2004 campaign was carried out. HONO measurements were conducted using rotated wet effluent diffusion denuder (WEDD) methods at two supersites: one at an urban area (GZ: $23.13^{\circ} \mathrm{N}, 113.26^{\circ} \mathrm{E}$ ) and one at a rural area $\left(\mathrm{XK}: 22.61^{\circ} \mathrm{N}, 113.59^{\circ} \mathrm{E}\right)$ (Fig. 1) (Zhang et al., 2008a). During the PRIDE-PRD2004 campaign period, the persistent surface high-pressure system (anticyclone), descent motion outside of hurricane and frequent sea breeze result in highlevel ground mixing ratio for gaseous and particulate pollutants (Fan et al., 2008). For instance, at XK supersite, at least two severe episodes were observed on October 25 and October 29 with measured daily peak $\mathrm{O}_{3}$ mixing ratio reaching over $150 \mathrm{ppb} \mathrm{V}$ and $\mathrm{PM}_{2.5}$ peak mixing ratio near or greater than $200 \mu \mathrm{g} \mathrm{m}^{-3}$ (Zhang et al., 2008a). 25 Observed maximum HONO mixing ratio in XK was reported to be more than $4 \mathrm{ppb} \mathrm{V}$ in the nighttime and about $1 \mathrm{ppb} V$ during the daytime (Su et al., 2008).

\section{Impact of nitrous acid chemistry on air quality}

R. Zhang et al.

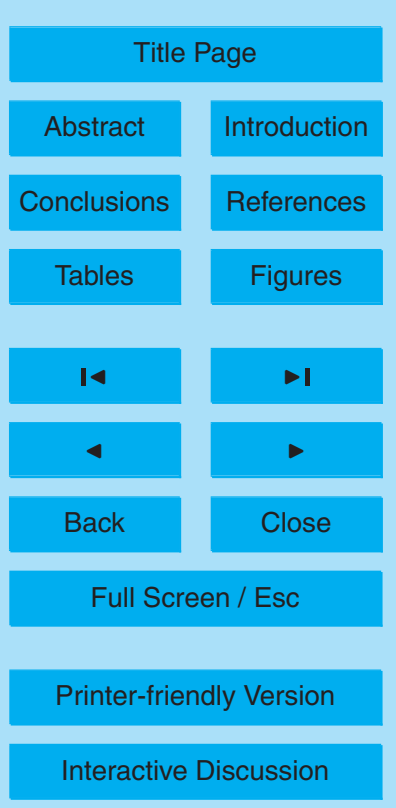


A total of eleven simulation cases were performed to investigate the impact of additional HONO formation pathways on air quality modeling results over PRD region. Sensitivity runs were designed to understand the impacts of uncertainties of selected parameters on air quality. Selected significance test on HONO prediction using the pre5 vious proposed parameterization methods were carried out to discuss their robustness over PRD region simulation. The impact of $\mathrm{HONO}$ chemistry on $\mathrm{O}_{3}$ control strategy due to the VOC emission reduction was also evaluated. The case ID, case description, and designed purpose are summarized in Table 1.

\section{Results and discussion}

\section{$10 \quad 3.1$ Model performance for base case CB05}

Time series of predicted $\mathrm{SO}_{2}, \mathrm{NO}_{\mathrm{x}}, \mathrm{O}_{3}$ and $\mathrm{PM}_{2.5}$, as well as aerosol sulfate and aerosol nitrate (case CB05, see Table 1) are compared to the measurements obtained from the Hong Kong Environmental Protection Department (HKEPD) for Yuen Long (YL) monitoring station (Fig. 3). Model performance statistics for other locations (CW, 15 TM, TW, TC, and YL) (see Fig. 1) are summarized in Table 2. Generally, CMAQ model has skill to reproduce air pollutant mixing ratios, their trends, spatial gradient, and relative abundance. Relatively high indexes of agreement $(\mathrm{IOA}>0.5)$ were obtained for all species except aerosol nitrate $\left(\mathrm{ANO}_{3}\right)$ Mean normalized bias (MNB) for $\mathrm{SO}_{2}, \mathrm{NO}_{\mathrm{x}}$, $\mathrm{O}_{3}$ and aerosol sulfate $\left(\mathrm{ASO}_{4}\right)$ are less than $\pm 30 \%$, which is taken as the acceptable level for model performance (USEPA, 2002).

While predicted $\mathrm{O}_{3}$ mixing ratios agree well with observed data reasonably as demonstrated by high IOA value, it cannot reproduce high observed afternoon $\mathrm{O}_{3}$ (Fig. 3). Model tends to underestimate $\mathrm{PM}_{2.5}$ mass mixing ratios uniformly by $40 \sim$ $50 \%$. This may be due to the underestimation of related PM emission rates and miss(Binkowski et al., 2003) allocates all unspecified aerosol components into the category

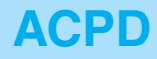

$11,15075-15117,2011$

\section{Impact of nitrous acid chemistry on air quality \\ R. Zhang et al.}

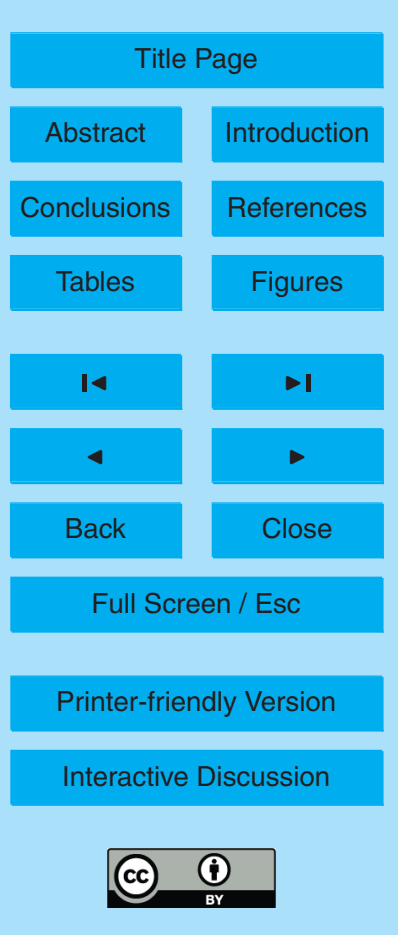


"PM_OTHER" and represents them as chemical inert. The modeled $\mathrm{PM}_{2.5}$ component has a large portion ( $25 \% \sim 40 \%$ ) of "PM_OTHER", which may cause the underestimation of specific aerosol component. Modeling results are consistent with the work reported by Kwok et al. (2010).

5 However, the CMAQ model has certain skill to represent sulfate formation pathways via gaseous-phase and aqueous-phase chemical reactions. The second pathway is especially important over PRD region due to high ambient $\mathrm{RH}$ and large fraction of cloud cover generally present throughout the year (Yu et al., 2005). Simulated $\mathrm{ASO}_{4}$ is reasonably good with IOA around 0.6 and MNB less than $\pm 25 \%$.

10 The poor nitrate $\left[\mathrm{ANO}_{3}\right]$ performance may be due to the high uptake coefficient for heterogeneous hydrolysis of $\mathrm{N}_{2} \mathrm{O}_{5}$ in the model. Davis et al. (2010) revised the parameterization for the uptake coefficient for heterogeneous hydrolysis of $\mathrm{N}_{2} \mathrm{O}_{5}$ which improves model performance for aerosol nitrate. Additional improvements of the representation of uptake coefficient for heterogeneous hydrolysis of $\mathrm{N}_{2} \mathrm{O}_{5}$ are 15 likely in the future. Rate constant for homogeneous hydrolysis of $\mathrm{N}_{2} \mathrm{O}_{5}$ used in CB05 and other mechanisms is also likely to be high. The International Union of Pure and Applied Chemistry (IUPAC) (Atkinson et al., 2004) suggested a value of $2.5 \times 10^{-22} \mathrm{~cm}^{3} \mathrm{molec}^{-1} \mathrm{~s}^{-1}$ which is used in CB05 (Yarwood et al., 2005). However, the IUPAC (2010) has recently lowered the rate constant to $1.0 \times 10^{-22} \mathrm{~cm}^{3} \mathrm{molec}^{-1} \mathrm{~s}^{-1}$. 20 The updates in the uptake coefficient for heterogeneous hydrolysis of $\mathrm{N}_{2} \mathrm{O}_{5}$, rate constant for homogeneous hydrolysis of $\mathrm{N}_{2} \mathrm{O}_{5}$, as well as the uncertainty in ammonia emission may also contribute to the overestimation. Ambient observed $\mathrm{O}_{3}$ and $\mathrm{PM}_{2.5}$ outside Hong Kong are not publicly available; thus predicted mixing ratios cannot be compared with observed data. In summary, model performance statistics simulation is reasonably well and the model is suitable for evaluating the impact of HONO chemistry over PRD region.
ACPD

$11,15075-15117,2011$

\section{Impact of nitrous acid chemistry on air quality}

R. Zhang et al.

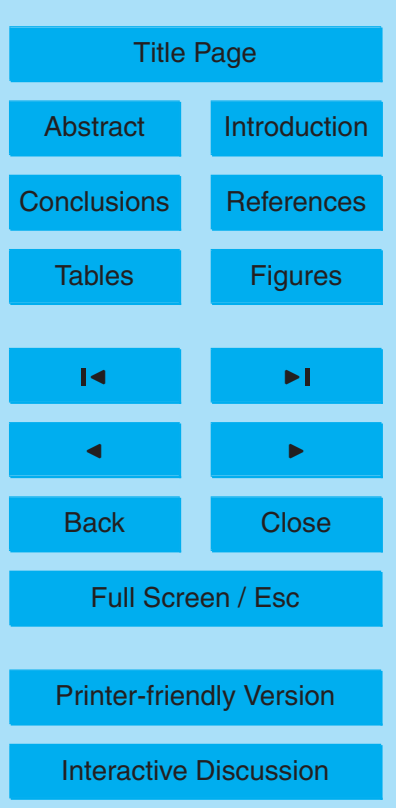




\subsection{Model evaluation at Xinken (XK) and Guangzhou (GZ)}

During the PRIDE_PRD2004 campaign, HONO was measured at XK and GZ (Zhang et al., 2008a). XK measurement site is located at a rural area while GZ measurements site is located at an urban area (Fig. 1). The model evaluation after incorporation

5 of different HONO chemistry at XK (first column) and GZ (second column) site for $\mathrm{NO}_{2}, \mathrm{O}_{3}$ and $\mathrm{HONO}$ are presented in Fig. 4. Daytime (07:00-18:00 LST) as well as nighttime (19:00-06:00 LST) model average values were compared with corresponding observations. The modeled $\mathrm{NO}_{2}$ mixing ratios for different simulation cases (Table 1) during daytime are underestimated by $26 \% \sim 28 \%$ at $\mathrm{XK}$ while during nighttime were overestimated at XK by $21 \% \sim 26 \%$ (no observation for $\mathrm{NO}_{2}$ available at $\mathrm{GZ}$ ). On the contrary, the modeled $\mathrm{O}_{3}$ mixing ratios are consistently underestimated at two sites and the degree of underestimation was more severe during daytime $(-34 \%$ at $\mathrm{XK}$ and $-40 \%$ at $\mathrm{GZ})$ than that during nighttime $(-28 \%$ at $\mathrm{XK}$ and $-10 \%$ at $\mathrm{GZ})$. The reason for the underestimation of $\mathrm{O}_{3}$ peaks may be associated with the overestimation of $\mathrm{NO}_{\mathrm{x}}$ and missing of $\mathrm{HONO}$ chemistry in base case CMAQ run. However, the HONO chemistry does not have obvious improvement on the $\mathrm{NO}_{2}$ and $\mathrm{O}_{3}$ model performance at $\mathrm{XK}$ and $\mathrm{GZ}$ sites during the campaign. In other places over PRD region, the HONO chemistry does have potential to enhance the simulated $\mathrm{O}_{3}$ peak value, which will be discussed in Sect. 3.6.

20 The modeled HONO mixing ratio increases by an order of magnitude after considering different HONO sources from direct emission, heterogeneous reactions as well as surface photolysis reactions. The simulation case $\mathrm{CB} 05+\mathrm{EM}+\mathrm{HT}+\mathrm{SP}$ can predict $40 \%$ and $36 \%$ of the observation values in XK (1.1 ppb V) and GZ (4.2ppb V) site, while the values for base case CB05 are only $4 \%$ and $2 \%$, respectively. Normal25 ized mean bias $(\mathrm{NMB})$ at $\mathrm{XK}$ is lower during nighttime $(\mathrm{NMB}=-48 \%)$ than that during daytime (NMB $=-71 \%)$, while at $\mathrm{GZ}$ site, the result is opposite $(\mathrm{NMB}=-63 \%$ during nighttime and $\mathrm{NMB}=-57 \%$ during daytime).

\section{Impact of nitrous acid chemistry on air quality \\ R. Zhang et al.}

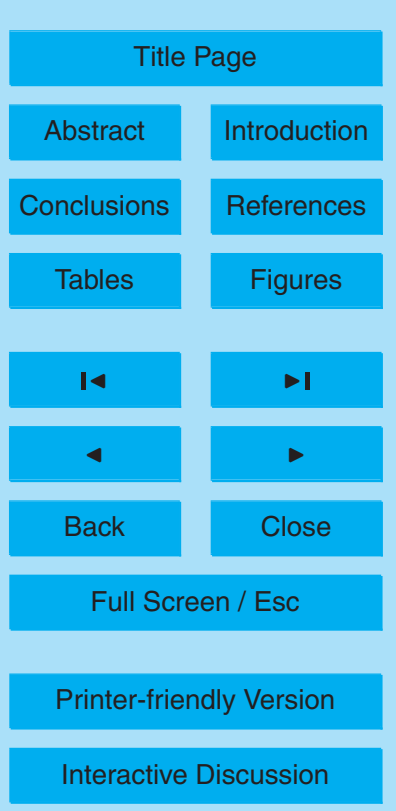


Predicted daytime average $\mathrm{OH}$ was $2.2 \times 10^{6}$ molec $\mathrm{cm}^{-3}$ at XK for case CB05 (homogeneous reactions only) which increased to $2.3 \times 10^{6} \mathrm{molec} \mathrm{cm}^{-3}, 2.4 \times$ $10^{6} \mathrm{molec} \mathrm{cm}^{-3}, 2.5 \times 10^{6} \mathrm{molec} \mathrm{cm}^{-3}$ for case CB05 + EM, CB05 + EM + HT, and case $\mathrm{CB} 05+\mathrm{EM}+\mathrm{HT}+\mathrm{SP}$, respectively. Predicted daytime average $\mathrm{OH}$ was $1.5 \times$ $510^{6} \mathrm{molec} \mathrm{cm}^{-3}$ at GZ for case CB05 (homogeneous reactions only) which increased to $1.7 \times 10^{6} \mathrm{molec} \mathrm{cm}^{-3}, 1.8 \times 10^{6} \mathrm{molec} \mathrm{cm}^{-3}, 1.9 \times 10^{6} \mathrm{molec}^{-3}$ for case CB05 + EM, $\mathrm{CB} 05+\mathrm{EM}+\mathrm{HT}$, and $\mathrm{CB} 05+\mathrm{EM}+\mathrm{HT}+\mathrm{SP}$, respectively. Thus, the additional HONO sources increased daytime $\mathrm{OH}$ by $13.6 \%$ and $26.7 \%$ at $\mathrm{XK}$ and $\mathrm{GZ}$, respectively.

\subsection{Spatial pattern of HONO simulation}

10 Spatial pattern of simulated HONO distributions during daytime (a-d) and nighttime (eh) are presented in Fig. 5 separately. The distribution patterns of simulated HONO for daytime and nighttime are generally consistent with the $\mathrm{NO}_{x}$ emission pattern, which is due to the fact that $\mathrm{HONO}$ formation pathways are related to $\mathrm{NO}_{2}$. Remarkable contrast for predicted daytime and nighttime HONO mixing ratio exists in different simulation

15 cases. Mean nighttime HONO mixing ratio is about twice to that of daytime value. For case $\mathrm{CB05}+\mathrm{EM}+\mathrm{HT}$, this night-to-day contrast is more pronounced. Over the $\mathrm{GZ}$ area, the mean daytime HONO mixing ratio is around $2 \mathrm{ppb} V$ while the predicted nighttime value is above $5 \mathrm{ppb} \mathrm{V}$.

The simulated HONO level from base case (case CB05) is low with the mean daytime value of less than $500 \mathrm{ppt} \mathrm{V}$ and nighttime value of $800 \mathrm{ppt} \mathrm{V}$. The addition of HONO emission (case CB05 + EM) increased predicted HONO by $2 \sim 3$ times. The heterogeneous reactions (case $\mathrm{CB} 05+\mathrm{EM}+\mathrm{HT}$ ) and surface photolysis (case $\mathrm{CB} 05+\mathrm{EM}+\mathrm{HT}+\mathrm{SP}$ ) further enhanced the modeled HONO level, which resulted in more than $8 \sim 10$ times greater than homogenous reaction only. Surface photolysis contributes more to the HONO enhancement during daytime due to the available of solar radiation (the difference between Fig. $5 \mathrm{c}$ and d), whereas heterogeneous reactions play a more important role in HONO formation at nighttime (the difference between

\section{ACPD}

$11,15075-15117,2011$

\section{Impact of nitrous acid chemistry on air quality}

R. Zhang et al.

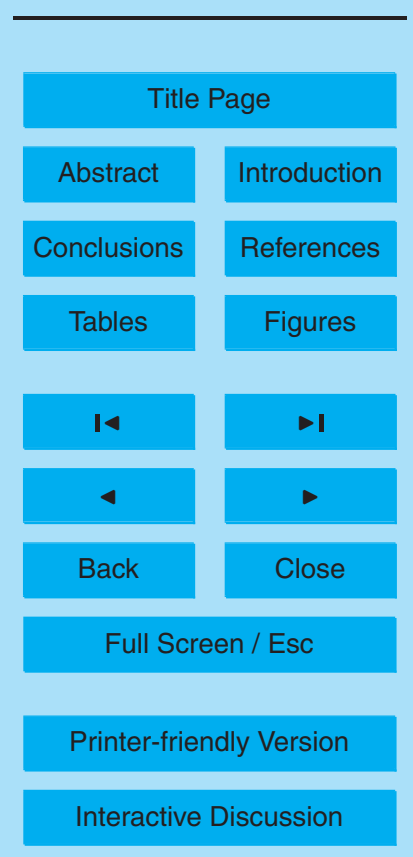


Fig. $5 \mathrm{~g}$ and $\mathrm{f}$ is as large as $200 \%$ ). Results are consistent with those reported by Sarwar et al. (2008).

\subsection{Relative contribution to HONO from different formation pathways}

The average contribution of homogenous reactions, direct emission, heterogeneous 5 reactions, and surface photolysis reaction to total simulated HONO at XK and GZ site during the entire simulation period site is presented in Fig. 6 . In rural site, heterogeneous reaction is the dominant contributor producing nearly $60 \%$ of predicted HONO. The importance of direct emission and surface photolysis is comparable with the contribution of around $15 \%$. Homogenous reactions contribute almost $10 \%$. While in urban site, the contribution of direct emission to the ambient HONO mixing ratio can reach to nearly $30 \%$. The average diurnal relative contribution of the four HONO sources to predicted HONO in XK and GZ site is shown in Fig. 7. Both in rural and urban site, the general diurnal pattern are similar. Nighttime HONO is primarily controlled by heterogeneous reaction which may account up to $89 \%$ in XK and $81 \%$ in GZ of predicted HONO. During daytime, the contribution of surface photolysis increases with the increase of solar radiation. The maximum contribution can reach up to $64 \%$ in XK and $31 \%$ in $\mathrm{GZ}$ at the late afternoon. The relative contribution of direct $\mathrm{HONO}$ emission in $\mathrm{XK}$ is greater at night and nearly negligible during the day when surface photolysis reaction as well as homogeneous reactions dominates. The relative contribution of direct HONO emissions at GZ is relatively high (20-30\%). A peak is observed during morning rush hour and a smaller peak is also observed in the evening rush hour. The relatively high contribution from direct emission at GZ suggests the importance of accurately speciating $\mathrm{NO}_{x}$ emission from vehicles (e.g. R13).

\subsection{Sensitivity study of different HONO simulation cases}

25 Three additional model simulations were conducted to investigate the sensitivity of different parameters on simulated HONO. The first parameter investigated is the $\mathrm{NO}_{\mathrm{x}}$

\section{Impact of nitrous acid chemistry on air quality \\ R. Zhang et al.}

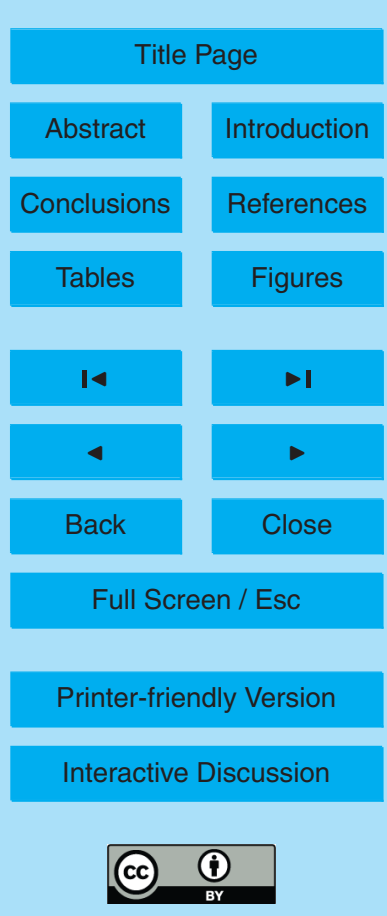


emission (from motor vehicle) speciation. For air quality modeling studies, $\mathrm{NO}_{\mathrm{x}}$ emissions are typically speciated into $\mathrm{NO}$ and $\mathrm{NO}_{2}$ by $90 \%$ and $10 \%$, respectively (by volume). Long term observation of $\mathrm{NO}_{2} / \mathrm{NO}$ ratio in Hong Kong from vehicle emission suggested that the traditional speciation for $\mathrm{NO}_{\mathrm{x}}$ emission may not be suitable 5 for PRD area (HKEPD, 2005). Higher $\mathrm{NO}_{2}$ emission contribution may be due to the unique condition of mobile fleet composition and engine type usage in Hong Kong. Hence, a sensitivity run (case HONO_NOX) by using alternative $\mathrm{NO}_{\mathrm{x}}$ emissions speciation is designed. For this study, $\mathrm{NO}_{x}$ was speciated into $\mathrm{NO}, \mathrm{NO}_{2}$, and $\mathrm{HONO}$ by $85 \%, 13.8 \%, 1.2 \%$. In this sensitivity run, the impact of increased direct HONO emis10 sion on predicted HONO is investigated. The second parameter for the sensitivity runs is the available surface area for heterogeneous reaction (case HONO_S/V). In case CB05, $[S / V]$ ratio for soil surface was set at $0.1 \mathrm{~m}^{-1}$ and the $[S / V]$ for building surface in Eq. (3) was estimated using a $s_{\max }=0.3 \mathrm{~m}^{-1}$. For PRD region, especially along the PRE area, the urban density and average building height is much higher than that in 15 US condition (HKPD, 2003), hence may provide more available interface for heterogeneous reaction. For this study, $s_{\max }=1.0 \mathrm{~m}^{-1}$ and $[S / V]_{\text {soil }}=0.2 \mathrm{~m}^{-1}$ were used. The third parameter is the HONO deposition velocity (case HONO_DV). An alternative lower deposition velocity taken the value of $\mathrm{NO}_{2}$ was used as the surrogate in the model to increase the chance for surface HONO accumulation.

20 Simulated mean $\mathrm{HONO}$ mixing ratios at $\mathrm{GZ}$ and $\mathrm{XK}$ for different simulation cases are presented in Fig. 8. Mean observed HONO at GZ is $4.17 \mathrm{ppb} V$ nearly four times greater than that at $\mathrm{XK}(1.12 \mathrm{ppb} \mathrm{V})$. GZ site is located at an urban area and $\mathrm{NO}_{2}$ mixing ratios are much greater than those at the rural XK site. Thus, observed HONO at GZ is much greater than that at XK. Homogenous reactions can only explain $5 \%$ or less of the observed HONO, whereas the heterogeneous reactions contribute more than $30 \%$ of observed value.

Compared with simulation case $\mathrm{CBO} 5+\mathrm{EM}+\mathrm{HT}+\mathrm{SP}$, HONO increases at GZ from sensitivity run HONO_DV, HONO_NO, HONO_S/V are 17\%, 13\% and 157\%, respectively; while at XK, the values are $37 \%, 9 \%$, and $207 \%$. Predicted HONO for

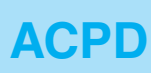

$11,15075-15117,2011$
Impact of nitrous acid chemistry on air quality
R. Zhang et al.

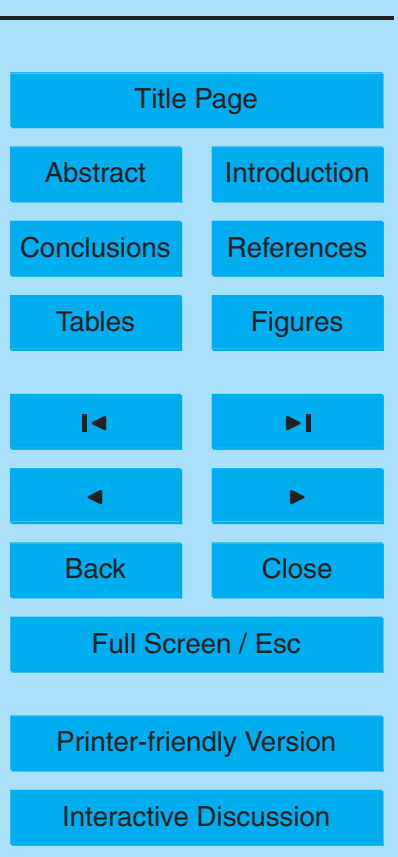


HONO_S/V case agrees well both at GZ and XK. Results of sensitivity runs underscore the importance of $[S / V]$ value for simulating HONO chemistry. While the PRD region has relatively high urban density and greater building height, the $s_{\max }$ value is not currently known. The model with $s_{\max }=1$ predicts HONO levels closer to the observed

5 data in PRD. The details of the HONO chemistry are still unknown. The use of currently known HONO reactions in air quality model does not re-produce observed HONO levels in PRD. Until the details of the HONO chemistry is known, this $s_{\max }$ value can be used in the model for PRD. This is an empirical parameter that produces HONO closer to observed data in PRD and is not intended for other urban areas.

10 We also implemented the production of $\mathrm{HONO}$ via heterogeneous reaction at ground using procedure described by Aumont et al. (2003) (case HONO_G). Consistent with the results reported Sarwar et al. (2008), predicted nighttime HONO was 30\%-67\% lower than the values obtained with $\mathrm{CB} 05+\mathrm{EM}+\mathrm{HT}+\mathrm{SP}$ and $66 \%-236 \%$ lower than the observed data.

15 The importance of HONO formation from heterogeneous reaction on semi-volatile organics was also examined (case HONO_SOA) using the procedure of Li et al. (2010). We also parameterized $\mathrm{HONO}$ production from diesel bound $\mathrm{NO}_{\mathrm{x}}$ emission using the conversion factor of 0.023 . The predicted mean HONO mixing ratios at GZ was $2.2 \pm 1.3 \mathrm{ppb} V$ while at $\mathrm{XK}$ was $0.54 \pm 0.37 \mathrm{ppb} \mathrm{V}$, which were underestimated around $50 \%$ compared with observed data (see Fig. 8). It should be noted that the maximum predicted daytime and nighttime HONO mixing ratio over PRD region exceeded $16 \mathrm{ppb} \mathrm{V}$ and $40 \mathrm{ppb} \mathrm{V}$, respectively, which is considered to be unrealistically high ( $\mathrm{Su}$ et al., 2008). This suggests that the contribution of the semi-volatile organics heterogeneous reaction to HONO formation is subject to high uncertainty.

\subsection{Impact of HONO chemistry on ozone and PM}

The spatial distribution of the largest enhancements of daily maximum 8-h $\mathrm{O}_{3}$ and daily mean $\mathrm{PM}_{2.5}$ due to the additional HONO sources are presented in Fig. 9. The largest enhancement occurred on 28 October with northeasterly moderate synoptic wind and

\section{Impact of nitrous acid chemistry on air quality \\ R. Zhang et al.}

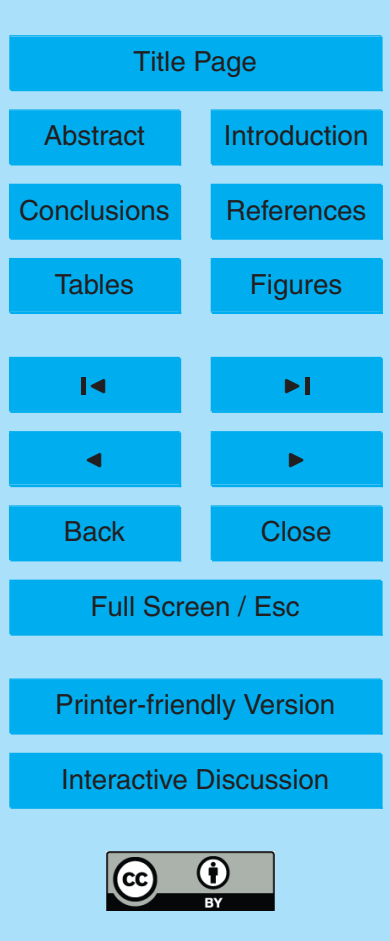


relatively steady atmosphere (Lin et al., 2008). Daily maximum 8-h $\mathrm{O}_{3}$ increased by up to $6 \mathrm{ppb} \mathrm{V}$ near the downwind of $\mathrm{GZ}$ city with simulated $\mathrm{O}_{3}$ level of $90 \mathrm{ppb} \mathrm{V}$ in base case run (case CB05). The impact on daily mean $\mathrm{PM}_{2.5}$ is relatively significant with the largest increase of nearly $17 \mathrm{\mu g} \mathrm{m}^{-3}$ or $12 \%$ at GZ, the downwind of GZ, Shenzhen 5 area and northwest of Hong Kong. The impact of additional HONO sources on aerosol sulfate and secondary organic aerosols was small; however the impact on ammonium and nitrate was relatively large (3.6 and $12.0 \mathrm{\mu g} \mathrm{m}^{-3}$, respectively) which subsequently enhanced $\mathrm{PM}_{2.5}$. The additional $\mathrm{OH}$ from the photolysis of enhanced $\mathrm{HONO}$ reacts with $\mathrm{NO}_{2}$ and produces additional $\mathrm{HNO}_{3}$ which subsequently generates greater aerosol 10 nitrate and ammonium.

The largest enhancement in morning $\mathrm{O}_{3}$ (08:00 a.m.-noon), daily maximum 8-h $\mathrm{O}_{3}$ and daily mean $\mathrm{PM}_{2.5}$ in the modeling domain for each day is shown in Table 3 . The largest enhancement in daily maximum 8- $\mathrm{O}_{3}$ ranged between $3-7 \mathrm{ppb} \mathrm{V}$ while the largest enhancement in morning $\mathrm{O}_{3}$ ranged between 3-9 ppb V. Levels of the morning ${ }_{15} \mathrm{O}_{3}$ increases are generally similar to those of daily maximum 8-h $\mathrm{O}_{3}$. The accumulated $\mathrm{HONO}$ at night undergoes photolysis during the day and produces $\mathrm{OH}$ which drives the photochemistry and enhances $\mathrm{O}_{3}$. The largest enhancement in daily mean $\mathrm{PM}_{2.5}$ ranged between $4-17 \mu \mathrm{g} \mathrm{m}^{-3}$. As mentioned earlier, ambient observed $\mathrm{O}_{3}$ and $\mathrm{PM}_{2.5}$ data in PRD region outside Hong Kong are not publicly available and thus increases in predicted mixing ratios cannot be compared with observed data.

The impact of additional $\mathrm{HONO}$ sources on $\mathrm{O}_{3}$ control strategy is also investigated. Urban areas of PRD are mostly VOC-limited for $\mathrm{O}_{3}$ production (Zhang et al., 2008a); thus only response of $25 \%$ VOC emission reduction was investigated (case $0.75 \mathrm{VOC}$ and $0.75 \mathrm{VOC} w / \mathrm{HONO}$ ). The relative response factor (RRF) is calculated to quantify 25 the response of $\mathrm{O}_{3}$ under different chemical mechanisms. RRF is the average ratio of simulated $\mathrm{O}_{3}$ mixing ratio with and without reduced emissions. RRF at several cities over PRD with and without additional HONO sources are presented at Fig. 10. Relatively high response was obtained in cities where intensive $\mathrm{NO}_{\mathrm{x}}$ and $\mathrm{VOC}$ emissions are present. The use of additional sources affected the RRF for many cities as shown

\section{Impact of nitrous acid chemistry on air quality}

R. Zhang et al.

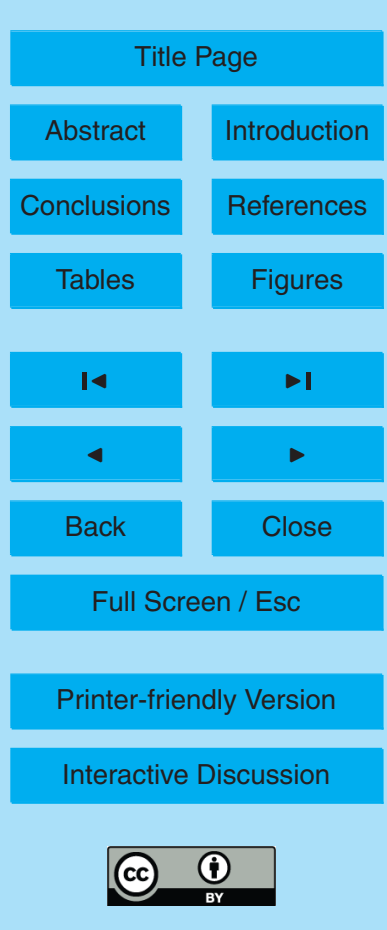


in the figure. For example, predicted RRF without the additional HONO sources at FS was $0.87\left(13 \% \mathrm{O}_{3}\right.$ decrease) due to the $25 \%$ VOC emission reduction. The inclusion of additional HONO sources changed the RRF to 0.85 or $15 \% \mathrm{O}_{3}$ decrease due to the same VOC emission reduction ( $2 \%$ increase in $\mathrm{O}_{3}$ response). Impact on RRF at other 5 cities was also similar. Thus, the use of additional HONO sources in the model affects the $\mathrm{O}_{3}$ control strategy.

\section{Summary}

This study investigated the contribution of HONO sources to the photochemistry over PRD. In addition to the gas phase reactions, three additional HONO formation path10 ways and direct emissions were incorporated into the model. The inclusion of additional sources improved HONO predictions significantly. Heterogeneous reaction is the dominant HONO source contributing nearly $60 \%$ of HONO formation, followed by surface photolysis and direct emission, with the contribution of around $15 \%$, respectively. The contribution from homogenous reaction is no more than $10 \%$ at both urban 15 and rural site. The inclusion of additional HONO sources enhanced daily maximum 8-h $\mathrm{O}_{3}$ by up to $7 \mathrm{ppb} V(8 \%)$ and daily average $\mathrm{PM}_{2.5}$ up to $17 \mu \mathrm{gm}^{-3}(12 \%)$. The use of additional $\mathrm{HONO}$ sources also affected the $\mathrm{O}_{3}$ control strategy.

Results of sensitivity studies suggest that the parameterization of surface area for heterogeneous reactions is an important factor that can affect simulated nitrous acid. 20 However, surface area estimates needed for these heterogeneous reactions are not currently available; hence implementations of these reactions in air quality models require simplifying assumptions. Thus, the details of these reactions (e.g., their dependence on types of surface, relative humidity, etc.) along with the estimates of available surface areas should be investigated in the future. The atmospheric chemistry com-

\section{ACPD}

$11,15075-15117,2011$

\section{Impact of nitrous acid chemistry on air quality \\ R. Zhang et al.}

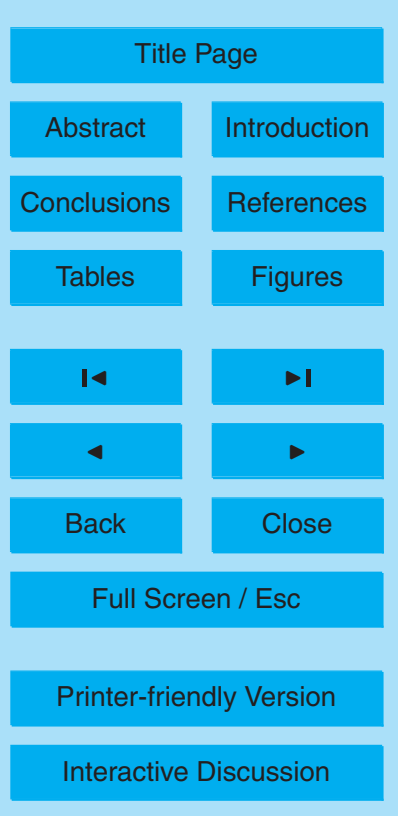
HONO sources will be identified in the future. When these additional HONO sources are known, the impact of HONO chemistry on air quality in PRD can be re-evaluated. 
Acknowledgement. This project was supported by HKUST Oversea Research Grant for PhD student, grants from the Research Grant Council of Hong Kong (RGC612807, RGC615406) and NSFC/RGC Joint Research Scheme (N_HKUST630/04, N_HKUST631/05). Although this paper has been reviewed by EPA and approved for publication, it does not necessarily reflect 5 EPA's polices or views.

\section{References}

Acker, K., Moller, D., Wieprecht, W., Meixner, F. X., Bohn, B., Gilge, S., Plass-Dulmer, C., and Berresheim, $\mathrm{H}$.: Strong daytime production of $\mathrm{OH}$ from $\mathrm{HNO}_{2}$ at a rural moutian site, Geophys. Res. Lett., 33, L02809, doi:10.1029/2005GL024643, 2006.

Ackermann, R.: Auswirkung von Kraftfahrzeugemissionen in der urbanen Atmosphare, Ph.D thesis, University of Heidelberg, Heidelberg, Germany, 2000.

Alicke, B., Platt, U., and Stutz, J.: Impact of HONO photolysis on the total hydroxyl radical budget during the Limitation of Oxidant Production/Pianura Padana Produzione di Ozone study in Milan, J. Geophys. Res., 107, 8196, doi:10.1029/2000JD000075, 2002.

15 Alicke, B., Geyer, A., Hofzumahaus, A., Holland, F., Konrad, S., Patz, H. W., Schafer, J., Stutz, J., Volz-Thomas, A., and Platt, U.: $\mathrm{OH}$ formation by HONO photolysis during the BERLIOZ experiment, J. Geophys. Res., 108(D4), 8247, doi:10.1029/2001JD000579, 2003.

Ammann, M., Kalberer, M., Jost, D. T., Tobler, L., Rossler, E., Piguet, D., Gaggeler, H. W., and Baltensperger, U.: Heterogeneous production of nitrous acid on soot in polluted air masses,

$20 \quad$ Nature, 395, 157-160, 1998.

Appel, B. R., Winer, A. M., Tokiwa, Y., and Bierman, H. W.: Comparison of atmospheric nitrous acid measurements by annular denuder and differential optical absorption systems, Atmos. Environ., 24A, 611-616, 1990.

Atkinson, R., Baulch, D. L., Cox, R. A., Crowley, J. N., Hampson, R. F., Hynes, R. G., Jenkin, M. E., Rossi, M. J., and Troe, J.: Evaluated kinetic and photochemical data for atmospheric chemistry: Volume I - gas phase reactions of $\mathrm{O}_{\mathrm{x}}, \mathrm{HO}_{\mathrm{x}}, \mathrm{NO}_{\mathrm{x}}$ and $\mathrm{SO}_{\mathrm{x}}$ species, Atmos. Chem. Phys., 4, 1461-1738, doi:10.5194/acp-4-1461-2004, 2004.

Aumout, B., Chervier, F., and Laval, S.: Contribution of HONO sources to the $\mathrm{NO}_{\mathrm{x}} / \mathrm{HO}_{\mathrm{x}} / \mathrm{O}_{3}$ chemistry in the polluted boundary layer, Atmos. Environ., 37, 487-498, 2003.

Binkowski, F. S. and Roselle, S. J.: Models-3 Community Multiscale Air Quality (CMAQ)

\section{Impact of nitrous acid chemistry on air quality}

R. Zhang et al.

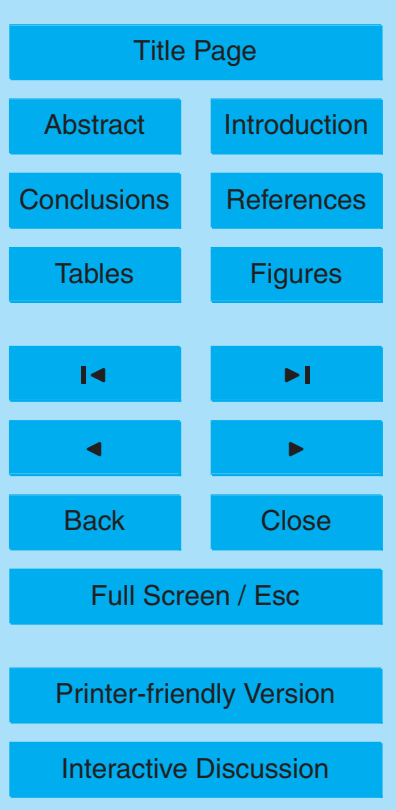


model aerosol component 1: model description, J. Geophys. Res., 108(D6), 4183, doi:10.1029/2001JD001409, 2003.

Byun, D. and Schere, K. L.: Review of the governing equations, computational algorithms, and other components of the Models-3 Community Multiscale Air Quality (CMAQ) modeling 5 system, Appl. Mech. Rev., 59, 51-77, 2006.

Calvert, J. G., Yarwood, G., and Dunker, A. M.: An evaluation of the mechanism of nitrous acid formation in the urban atmosphere, Res. Chem. Intermediat., 20, 463-502, 1994.

Cai, C. X.: Implementation and performance evaluation on an air quality forecast modeling system (AQFMS) for northeastern USA, PhD dissertation, Department of Earth and Atmo10 spheric Science, University at Albany, State University of New York, 2005.

CH2M HILL (China) Limited: Study of air quality in the Pearl River Delta region, technique report (Agreement No. CE 106/98) prepared for the Hong Kong Environmental Protection Department, Hong Kong Administrative Region Government, available at: http://www.epd. gov.hk/epd/english/environmentinhk/air/studyrpts/study_pearl.html (last access: May 2011), 152003.

Elshorbany, Y. F., Kurtenbach, R., Wiesen, P., Lissi, E., Rubio, M., Villena, G., Gramsch, E., Rickard, A. R., Pilling, M. J., and Kleffmann, J.: Oxidation capacity of the city air of Santiago, Chile, Atmos. Chem. Phys., 9, 2257-2273, doi:10.5194/acp-9-2257-2009, 2009.

ENVIRON International Corporation: User's guide for Comprehensive Air Quality Model with Extensions (CAMx), available at: http://www.camx.com/files/CAMxUsersGuide_v5.20.pdf (last access: May 2011), 2000.

Fan, S. J., Wang, B. M., Tesche, M., Engelmann, R., Althausen, A., Liu, J., Zhu, W., Fan, Q., Li, M. H., Ta, N., Song, L. L., and Leong, K.: Meteorological conditions and structures of atmospheric boundary layer in October 2004 over Pearl River Delta area, Atmos. Environ., 42, 6174-6186, 2008.

Fu, J., Jang, C., Streets, D., Li, Z. P., He, K. B., Wang, L. T., Zhang, Q., and Woo, J. H.: Regional/urban air quality modeling in Beijing and Shanghai, 4th Annual CMAS Model-3 user's Conference, Chapel Hill, NC, 26-28 September 2005.

Grell, G. A., Dudhia, J., and Stauffer, D. R.: A description of the fifth-generation Penn State/NCAR mesoscale model (MM5), NCAR technical note NCAR/TN-398+STR National Center for Atmospheric Research, Boulder, CO, 1994.

Gutzwiller, L., Arens, F., Baltensperger, U., Gaggeler, H. W., and Ammann, M.: Significance of semivolatile diesel exhaust organics for secondary HONO formation, Environ. Sci. Technol.,

\section{Impact of nitrous acid chemistry on air quality}

R. Zhang et al.

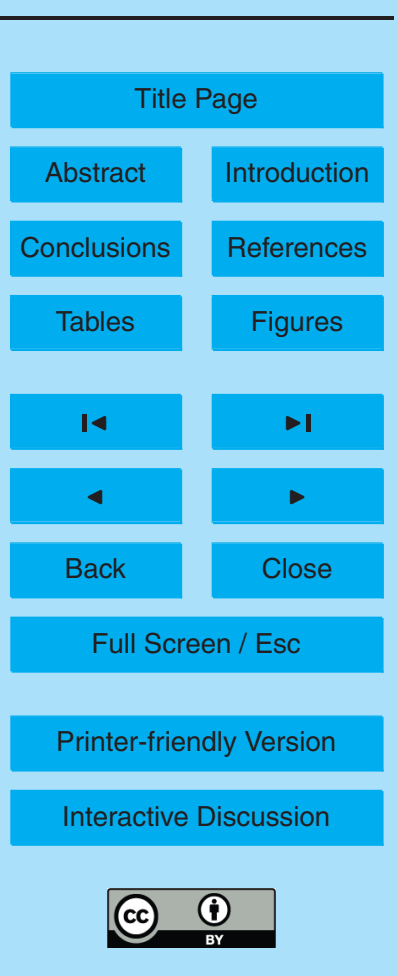


36, 677-682, 2002.

Harris, G. W., Cater, W. P. L., Winer, A. M., Pitts, J. N., Platt, U., and Perner, D.: Observations of nitrous acid in the Los Angeles atmosphere and implications for the predictions of ozoneprecursor relationships, Environ. Sci. Technol., 16, 414-419, 1982.

5 HKEPD: Guideline on modeling vehicle emissions, available at: http://www.epd.gov.hk/epd/ english/environmentinhk/air/guide_ref/files/EMFAC_HK_Guidelines_on_Modelling_Vehicle_ Emissions_July2005.pdf (last access: May 2011), July 2005.

HKPD (Hong Kong Planning Department): Hong Kong 2030: planning vision and strategy consultancy study to analyze broad land use pattern of the Pearl River Delta Region, available at: http://www.info.gov.hk/hk2030/hk2030content/wpapers/cover_wg/htm (last access: January 2011), 2003.

Houyoux, M. R., Vukovich, J. M., Coats Jr., C. J., Wheeler, N. M., and Kasibhatla, P. S.: Emission inventory development and processing for the Seasonal Model for Regional Air Quality (SMRAQ) project, J. Geophys. Rev., 105, 9079-9090, 2000.

15 Hu, M., Zhou., F. M., Shao, K. S., Zhnag, Y. H., Tang, X. Y., and Slanina, J.: Diurnal variations of aerosol chemical compositions and related gaseous pollutants in Beijing and Guangzhou, J. Environ. Sci. Health A, 37, 479-488, 2002.

Huang, J. P., Fung, J. C. H., and Lau, A. K. H.: Integrated processes analysis and systematic meteorological classification of ozone episodes in Hong Kong, J. Geophys. Res., 110,

$20 \quad$ D20309, doi:10.1029/2005JD007012, 2006.

Hutzell, W. T., Roselle, S. J., Carlton, A. G., and Bullock, O. R.: Changes to the multi-pollutant version in the CAMQ4.7, 7th Annual CMAS Conference, 6-8 October 2008, Chapel Hill, NC, 2008.

IUPAC: Subcommittee for Gas Kinetic Data Evaluation, available at: http://www.iupac-kinetic. ch.cam.ac.uk (last access: May 2011), 2010.

Jenkin, M. I., Cox, R. A., and Williams, D. J.: Laboratory studies of the kinetic of formation of nitrous acid from thermal reaction of nitrogen dioxide and water vapor, Atmos. Environ., 22, 487-498, 1988.

Jones, M. R.: Ammonia deposition to semi-natural vegetation, $\mathrm{PhD}$ dissertation, University of Dundee, Dundee, Scotland, 2006.

Kessler, C. and Platt, U.: Nitrous acid in polluted air masses-sources and formation pathways, in: Physico-Chemical Behaviour of Atmospheric Pollutants (Proceedings), edited by: Versino, B. and Angeletti, G., Reidel, Dordrecht, 412-422, 1984.

\section{Impact of nitrous acid chemistry on air quality}

R. Zhang et al.

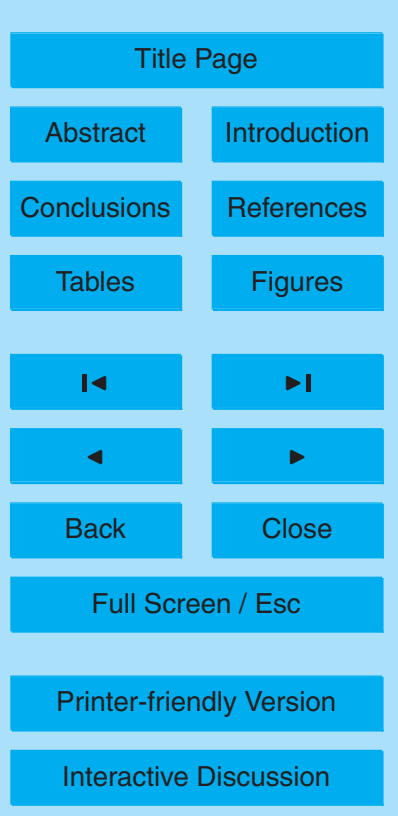


Kleffmann, J.: Daytime sources of nitrous acid (HONO) in the atmospheric boundary layer, Chem. Phys. Chem., 8, 1137-1144, 2007.

Kleffmann, J., Gavriloaiei, T., Hofzumahaus, A., Holland, F., Koppmann, R., Rupp, L., Schlosser, E., Siese, M., and Wahner, A.: Daytime formation of nitrous acid: a major source of $\mathrm{OH}$ radicals in a forest, Geophys. Res. Lett., 32, L05818, doi:10.1029/2005GL022524, 2005.

Knipping, E. M. and Dabdub, D.: Modeling surface-mediated renoxification of the atmosphere via reaction of gaseous nitric oxide with deposited nitric acid, Atmos. Environ., 36, 57415748, 2002.

Kirchstetter, T. W. and Littlejohn, D.: Measurements of nitrous acid in motor vehicle exhaust, Environ. Sci. Technol., 30, 2843-2849, 1996.

Kurtenbach, R., Becker, K. H., Gomes, J. A. G., Kleffmann, J., Lorzer, J. C., Spittler, M., Wiesen, P., Ackermann, R., Geyer, A., and Platt, U.: Investigations of emissions and heterogeneous formation of HONO in a road traffic tunnel, Atmos. Environ., 35, 3385-3394, 2001.

Kwok, R. H. F., Fung, J. C. H., Lau, A. K. H., and Fu, J. S.: Numerical study on seasonal variations of gaseous pollutants and particulate matters in Hong Kong/Pearl River Delta Region, J. Geophys. Res., 115, D16308, doi:10.1029/2009JD012809, 2010.

Lei, W., Zhang, R., Tie, X., and Hess, P.: Chemical characterization of ozone formation in the Houston-Galveston area: a chemical transport model study, J. Geophys. Res., 109, D12301, doi:10.1029/2003JD004219, 2004.

Li, G., Lei, W., Zavala, M., Volkamer, R., Dusanter, S., Stevens, P., and Molina, L. T.: Impacts of HONO sources on the photochemistry in Mexico City during the MCMA-2006/MILAGO Campaign, Atmos. Chem. Phys., 10, 6551-6567, doi:10.5194/acp-10-6551-2010, 2010.

Li, S., Matthews, J., and Sinha, A.: Atmospheric hydroxyl radical production from electronically excited $\mathrm{NO}_{2}$ and $\mathrm{H}_{2} \mathrm{O}$, Science, 319, 1657-1660, 2008.

Lo, J. C. F., Lau, A. K. H., Fung, J. C. H., and Chen, F.: Investigation of enhanced cross-city transport and trapping of air pollutants by costal and urban land-sea breeze circulations, J. Geophys. Res., 111, D14104, doi:10.1029/2005JD006837, 2006.

30 Lu, X., Chow, K. C., Yao, T., Fung, J. C. H., and Lau, A. K. H.: Seasonal variation of the land-sea breeze circulation in the Pearl River Delta region, J. Geophys. Res., 114, D17112, doi:10.1029/2009JD011764, 2009.

Lu, K. D., Zhang, Y. H., Su, H., Shao, M., Zeng, L. M., Zhong, L. J., Xiang, Y. R., Chang, C. C.,

\section{Impact of nitrous acid chemistry on air quality}

R. Zhang et al.

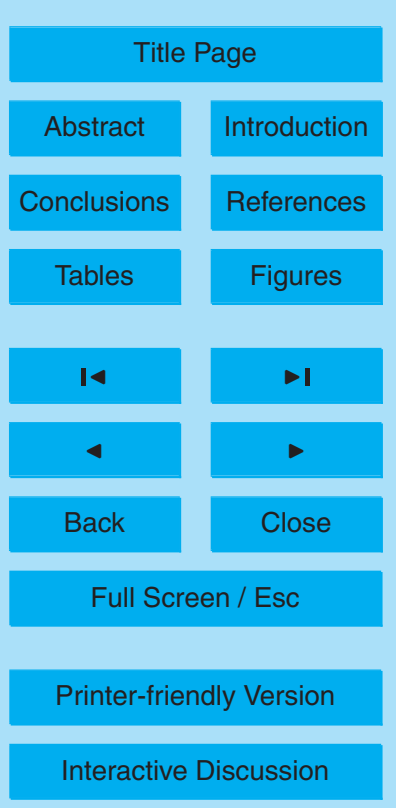


Chou, C. K. C., and Andreas, W.: Regional ozone pollution and key controlling factors of photochemical ozone production in Pearl River Delta during summer time, Sci. China Chem., 53, 651-663, 2010.

Mao, Q., Gautney, L. L., Cook, T. M., Jacobs, M. E., Smith, S. N., and Kelsoe, J. J.: Numerical 5 experiments on MM5-CMAQ sensitivity to various PBL schemes, Atmos. Environ., 40, 30923110, 2006.

Nenes, A., Pilinis, C., and Pandis, S. N.: ISORROPIA: a new thermodynamic model for multiphase multicomponent inorganic aerosols, Aquat. Geochem., 4, 123-152, doi:10.1023/A:1009604003981, 1998.

10 Pleim, J. E. and Chang, J. S.: A non-local closure model for vertical mixing in the convective boundary layer, Atmos. Environ., 26A, 965-981, 1992.

Qin, M., Xie, P. H., Su, H., Gu, J. W., Peng, F. M., Li, S. W., Zeng, L. M., Liu, J. G., Liu, W. Q., and Zhang, Y. H.: An observational study of the HONO-NO ${ }_{2}$ coupling at urban site in Guangzhou City, South China, Atmos. Environ., 43, 5731-5742, 2009.

Ramazan, K. A., Syomin, D., and Finlayson-Pitts, J. B.: The photochemical production of HONO during the heterogeneous hydrolysis of $\mathrm{NO}_{2}$, Phys. Chem. Chem. Phys., 6, 3836-3843, 2004.

Ren, X., Brune, W. H., Oliger, A., Metcalf, A. R., Simpas, J. B., Shirley, T., Schwab, J. J., Bai, C., Roychowdhury, U., Li, Y., Cai, C., Demerjian, K. L., He, Y., Zhou, X., Gao, H. and Hou, J.: OH, $\mathrm{HO}_{2}$ and $\mathrm{OH}$ reactivity during the PMTACS-NY Whiteface Moutain 2002 Campaign: observations and model comparison, J. Geophys. Res., 111, D10S03, doi:10.1029/2005JD006126, 2006.

Rivera-Figueroa, A. M., Sumner, A. L., and Finlayson-Pitts, B. J.: Laboratory studies of potential mechanism of renoxification of tropospheric nitric acid, Environ. Sci. Technol., 37, 548-554, 252003.

Sarwar, G., Roselle, S. J., Mathur, R., Appel, W., Dennis, R. L., and Vogel, B.: A comparison of CMAQ HONO predictions with observations from the Northeast Oxidant and Particle Study, Atmos. Environ., 42, 5760-5770, 2008.

Shell, B., Ackermann, I. J., Hass, H., Binkowski, F. S., and Ebel, A.: Modeling the formation of secondary organic aerosol within a comprehensive air quality model system, J. Geophys. Res., 106(D22), 28275-28293, doi:10.1029/2001JD000384, 2001.

Staffelbach, T., Neftel, A., and Horowitz, L. W.: Photochemical oxidant formation over Southern Switzerland, 2, Model results, J. Geophys. Res., 102, 23363-23373, 1997.

\section{Impact of nitrous acid chemistry on air quality}

R. Zhang et al.

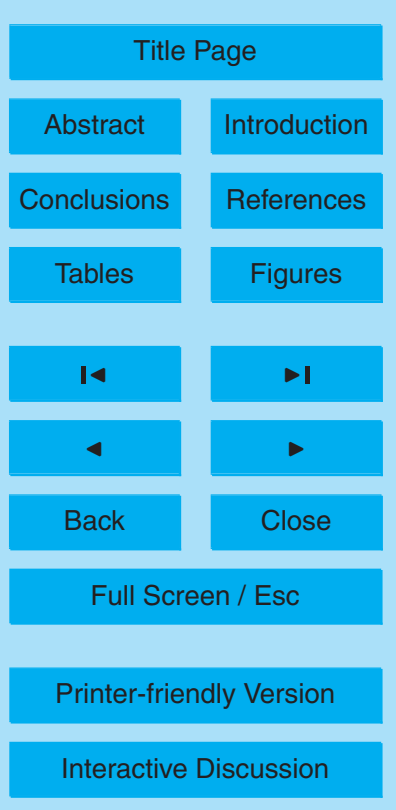


Stemmler, K., Ammann, M., Dondors, M., Kleffmann, J., and George, C.: Photosensitized reduction of nitrogen dioxide on humic acid as a source of nitrous acid, Nature, 440, 195-198, 2006.

Stemmler, K., Ndour, M., Elshorbany, Y., Kleffmann, J., D’Anna, B., George, C., Bohn, B., and 5 Ammann, M.: Light induced conversion of nitrogen dioxide into nitrous acid on submicron humic acid aerosol, Atmos. Chem. Phys., 7, 4237-4248, doi:10.5194/acp-7-4237-2007, 2007.

Stutz, J., Alicke, B., Ackermann, R., Geyer, A., Wang, S. H., White, A. B., Williams, E. J., Spicer, C. W., and Fast, J. D.: Relative humidity dependence of HONO chemistry in urban areas, J. Geophys. Res., 109, D03007, doi:10.1029/2003JD004135, 2004.

10 Su, H., Cheng, Y. F., Cheng, P., Zhang, Y. H., Dong, S. F., Zeng, L. M., Wang, X. S., Slanina, J., Shao, M., and Wiedensohler, A.: Observation of nighttime nitrous acid (HONO) formation at a non-urban site during PRIDE-PRD2004 in China, Atmos. Environ., 42, 6219-6232, 2008.

Svensson, R., Ljungstrom, E., and Lindqvist, O.: Kinetics of the reaction between nitrogen dioxide and water vapor, Atmos. Environ., 21, 1529-1539, 1987.

USEPA: Guidance on the use of models and other analyses in attainment demonstrations for the 8-h ozone NAAQS, EPA-454/R-99-004, US Environmental Protection Agency, Research Triangle Park, NC, US, 1999.

USEPA: SPECIATE data base V3.1, Research Triangle Park, NC, US, available at: http://www. epa.gov/ttn/chief/software/speciate/speciate32.html (last access: May 2011), 2000.

Vogel, B., Vogel, H., Kleffmann, J., and Kurtenbach, R.: Measured and simulated vertical profiles of nitrous acid - Part II, Model simulations and indications for a photolytic source, Atmos. Environ. 37, 2957-2966, 2003.

Winer, A. M. and Biermann, H. W.: Long pathlength differential optical absorption spectroscopy (DOAS) measurements of gaseous $\mathrm{HONO}, \mathrm{NO}_{2}$ and $\mathrm{HCHO}$ in the California South Coast Air Basin, Res. Chem. Intermediat., 20, 423-445, 1994.

Yarwood, G., Rao, S., Yocke, M., and Whitten, G.: Updates to the carbon bond chemical mechanism: CB05, Final report to the US EPA, RT-0400675, available at http://www.camx.com (last access: May 2011), 2005.

Yim, S. H. L., Fung, J. C. H., Lau, A. K. H., and Kot, S. C.: Developing a high-resolution wind 30 map for a complex terrain with a coupled MM5/CLAMET system, J. Geophys. Res., 112, D05106, doi:10.1029/2006JD007752, 2007.

Yu, J. Z., Huang, X. F., Xu, J., and Hu, M.: When sulfate goes up, so does oxalate: implication for the formation mechanisms of oxalate, Environ. Sci. Technol., 39, 128-133, 2005.

\section{Impact of nitrous acid chemistry on air quality}

R. Zhang et al.

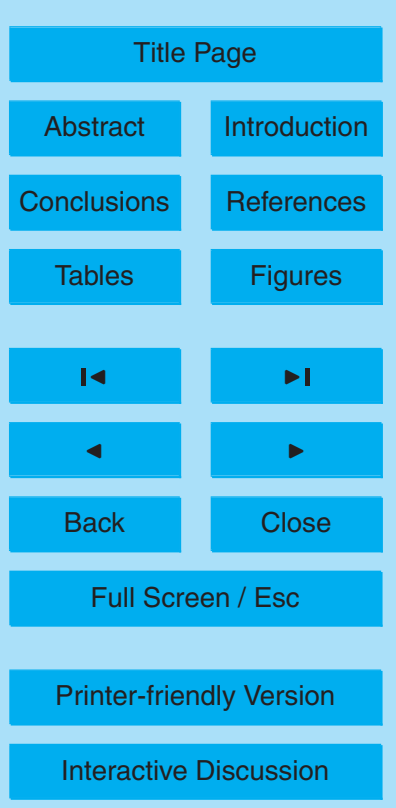


Zhang, Y. H., Hu, M., Zhong, L. J., Wiedensohler, A., Liu, S. C., Andrease, M. O., Wang, W., and Fan, S. J.: Regional integrated experiments on air quality over Pearl River Delta 2004 (PRIDE-PRD2004): overview, Atmos. Environ., 42, 6157-6173, 2008a.

Zhang, Y. H., Su, H., Zhong. L. J., Cheng, Y. F., Zeng, L. M., Wang, X. S., Xiang, Y. R., Wang, J. L., Gao, D. F., Shao, M., Fan, S. J., and Liu, S. C.: Regional ozone pollution and observation-based approach for analyzing ozone-precursor relationship during the PRIDEPRD2004 campaign, Atmos. Environ., 42, 6203-6218, 2008b.

Zhou, X., Civerolo, K., Dai, H., Huang, G., Schwab, J. J., and Dermerjian, K. L.: Summertime nitrous acid chemistry in the atmospheric boundary layer at a rural site in New York state, J. Geophys. Res., 107(D21), 4590, doi:10.1029/2001JD001539, 2002.

Zhou, X. L., Gao, H. L., He, Y., Huang, G., Bertman, S. B., Civerolo, K., and Schwab, J.: Nitric acid photolysis on surfaces in low- $\mathrm{NO}_{\mathrm{x}}$ environments: significant atmospheric implications, Geophys. Res. Lett., 30, 2217, doi:10.1029/2003GL018620, 2003.

\section{ACPD}

$11,15075-15117,2011$

\section{Impact of nitrous acid chemistry on air quality}

R. Zhang et al.

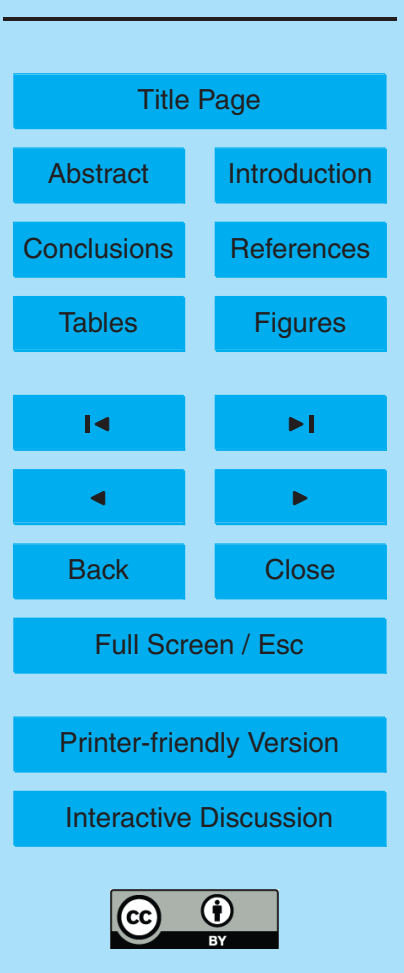


Table 1. Design of CMAQ simulation case to evaluate the HONO chemistry.

\begin{tabular}{|c|c|c|}
\hline Case ID & Description & Purpose \\
\hline $\begin{array}{l}\text { CB05 } \\
\text { CB05 + EM } \\
\text { CB05 + EM } \\
+ \text { HT } \\
\text { CB05 + EM } \\
+\mathrm{HT}+\mathrm{SP}\end{array}$ & $\begin{array}{l}\text { Base case run } \\
\text { CB05 + HONO emission (R13) } \\
\text { CB05 + EM + HONO heterogeneous } \\
\text { reaction }(R 6, R 8) \\
\text { CB05 + EM + HT + HONO surface } \\
\text { photolysis (R11, R12) }\end{array}$ & $\begin{array}{l}\text { Relative importance of four } \\
\text { different formation pathways } \\
\text { to simulated HONO }\end{array}$ \\
\hline HONO_S/V & $\begin{array}{l}\mathrm{CB} 05+\mathrm{EM}+\mathrm{HT}+\mathrm{SP} \text { with } S_{\max }=1 \text { in } \\
\text { building surface area estimation, and soil } \\
\text { surface } 0.2\end{array}$ & $\begin{array}{l}\text { Sensitivity study of the } \\
\text { uncertainties for selected } \\
\text { parameters in HONO }\end{array}$ \\
\hline HONO_NOX & $\begin{array}{l}\mathrm{CB} 05+\mathrm{EM}+\mathrm{HT}+\mathrm{SP} \text { with } \mathrm{NO}_{x} \text { emission } \\
\text { partition } \mathrm{NO} / \mathrm{NO}_{2} / \mathrm{HONO} 85 \% / 13.8 \% / \\
1.2 \%\end{array}$ & \\
\hline HONO_DV & $\begin{array}{l}\mathrm{CB} 05+\mathrm{EM}+\mathrm{HT}+\mathrm{SP} \text { with deposition } \\
\text { velocity of } \mathrm{HONO} \text { taken the value as } \mathrm{NO}_{2}\end{array}$ & \\
\hline HONO_G & $\begin{array}{l}\mathrm{CB} 05+\mathrm{EM}+\mathrm{SP}+\mathrm{HONO} \text { heterogeneous } \\
\text { reaction on aerosol and ground surfaces } \\
\text { follow Aumont et al. (2003) }\end{array}$ & $\begin{array}{l}\text { Examine the impacts of other } \\
\text { HONO parameterizations } \\
\text { published in peer-reviewed }\end{array}$ \\
\hline HONO_SOA & $\begin{array}{l}\text { CB05 + HONO heterogeneous reaction } \\
\text { with semivolatile organic follow Li et al. } \\
(2010)\end{array}$ & articles \\
\hline $0.75 \mathrm{VOC}$ & $\begin{array}{l}\text { CB0 } 5 \text { with the } 25 \% \text { VOC emission } \\
\text { reduction over PRD region }\end{array}$ & $\begin{array}{l}\text { Evaluation the possible effect } \\
\text { on ozone control strategy due }\end{array}$ \\
\hline $\begin{array}{l}0.75 \mathrm{VOC} \\
\mathrm{w} / \mathrm{HONO}\end{array}$ & $\begin{array}{l}\mathrm{CB} 05+\mathrm{EM}+\mathrm{HT}+\mathrm{SP} \text { with the } 25 \% \mathrm{VOC} \\
\text { emission reduction over PRD region }\end{array}$ & $\begin{array}{l}\text { to consideration of additional } \\
\text { HONO formation pathway }\end{array}$ \\
\hline
\end{tabular}

Impact of nitrous acid chemistry on air quality

R. Zhang et al.

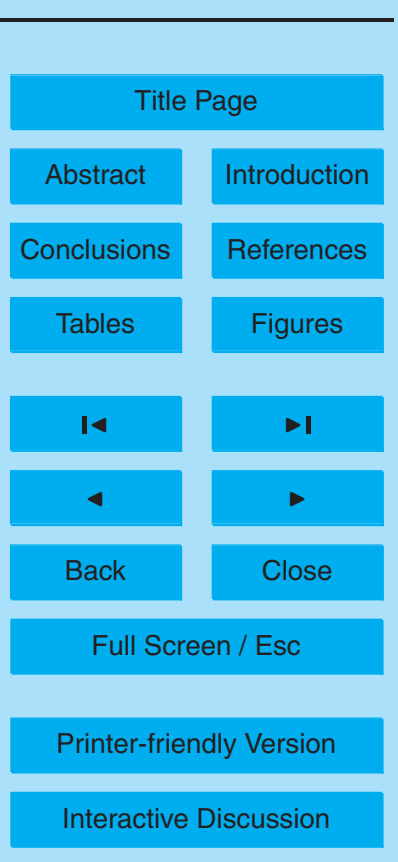


Table 2. Model performance of gaseous pollutant and particulate matter simulation over Hong Kong in October 2004 for case CB05.

\begin{tabular}{|c|c|c|c|c|c|c|c|}
\hline & & $\begin{array}{l}\mathrm{SO}_{2} \\
(\mathrm{ppb})\end{array}$ & $\begin{array}{l}\mathrm{NO}_{\mathrm{x}} \\
(\mathrm{ppb})\end{array}$ & $\begin{array}{c}\mathrm{O}_{3} \\
(\mathrm{ppb})\end{array}$ & $\begin{array}{c}\mathrm{PM}_{2.5} \\
\left(\mu \mathrm{g} \mathrm{m}^{-3}\right)\end{array}$ & $\begin{array}{c}\mathrm{ASO}_{4} \\
\left(\mu \mathrm{g} \mathrm{m}^{-3}\right)\end{array}$ & $\begin{array}{c}\mathrm{ANO}_{3} \\
\left(\mu \mathrm{g} \mathrm{m}^{-3}\right)\end{array}$ \\
\hline \multirow[t]{6}{*}{$\mathrm{CW}$} & Obv & 18.6 & 47.3 & 42.5 & 76.2 & 21.6 & 4.4 \\
\hline & Sim & 14.9 & 50.6 & 36.4 & 40.7 & 17.3 & 8.9 \\
\hline & $\mathrm{IOA}^{*}$ & 0.54 & 0.68 & 0.73 & 0.48 & 0.54 & 0.11 \\
\hline & $\mathrm{RMSE}^{*}$ & 4.8 & 20 & 14.3 & 41.3 & 12.1 & 36.9 \\
\hline & $\mathrm{MNB}^{*}(\%)$ & -19.3 & 7.3 & -23.6 & -44.6 & -16.9 & 87.5 \\
\hline & MNE $^{*}(\%)$ & 39.3 & 48.6 & 42.5 & 45.5 & 38.9 & 89.6 \\
\hline \multirow[t]{6}{*}{ TM } & Obv & 8.6 & 18.6 & 63.2 & 62.5 & - & - \\
\hline & Sim & 5.0 & 9.2 & 59.3 & 38.8 & - & - \\
\hline & $\mathrm{IOA}^{*}$ & 0.44 & 0.44 & 0.75 & 0.51 & - & - \\
\hline & RMSE $^{*}$ & 3.6 & 11 & 11.1 & 33.6 & - & - \\
\hline & $\operatorname{MNB}^{*}(\%)$ & -26.9 & -50.2 & -3.9 & -39.8 & - & - \\
\hline & $\mathrm{MNE}^{*}(\%)$ & 52.1 & 57.3 & 25.1 & 48.2 & - & - \\
\hline \multirow[t]{6}{*}{ TW } & Obv & 11.0 & 70.6 & 53.7 & 69.3 & - & - \\
\hline & Sim & 6.8 & 62.8 & 30.2 & 35.5 & - & - \\
\hline & IOA* & 0.43 & 0.59 & 0.52 & 0.50 & - & - \\
\hline & $\mathrm{RMSE}^{*}$ & 4.5 & 39 & 21.6 & 40.9 & - & - \\
\hline & $\mathrm{MNB}^{*}(\%)$ & -40.3 & -10.6 & -47.6 & -40.5 & - & - \\
\hline & $\operatorname{MNE}^{*}(\%)$ & 48.3 & 55.2 & 79.6 & 44.6 & - & - \\
\hline \multirow[t]{6}{*}{ TC } & Obv & 16.9 & 43.2 & 80.6 & 72.6 & - & - \\
\hline & Sim & 11.2 & 36.1 & 59.1 & 44.9 & - & - \\
\hline & $1 O A^{*}$ & 0.58 & 0.71 & 0.77 & 0.43 & - & - \\
\hline & $\mathrm{RMSE}^{*}$ & 6.9 & 21 & 18.2 & 45.1 & - & - \\
\hline & $\mathrm{MNB}^{*}(\%)$ & -26.3 & -10.8 & -33.2 & -40.6 & - & - \\
\hline & $\mathrm{MNE}^{*}(\%)$ & 50.3 & 47.2 & 54.3 & 42.5 & - & - \\
\hline \multirow[t]{6}{*}{ YL } & Obv & 24.9 & 84.1 & 89.3 & 72.6 & 18.3 & 6.9 \\
\hline & Sim & 18.6 & 47.6 & 60.2 & 45.1 & 14.3 & 7.8 \\
\hline & $1 O A^{*}$ & 0.49 & 0.65 & 0.81 & 0.56 & 0.56 & 0.19 \\
\hline & $\mathrm{RMSE}^{*}$ & 5.2 & 36 & 15.3 & 40.2 & 10.3 & 6.5 \\
\hline & $\mathrm{MNB}^{*}(\%)$ & -22.1 & -40.1 & -28.1 & -45.1 & -23.5 & 19.1 \\
\hline & $\mathrm{MNE}^{*}(\%)$ & 44.1 & 54.1 & 39.9 & 49.6 & 39.6 & 45.8 \\
\hline
\end{tabular}

* IOA-index of agreement, RMSE-root mean square error, MNB-mean normalized bias, MNE-mean normalized error.

\section{ACPD}

11, 15075-15117, 2011

Impact of nitrous acid chemistry on air quality

R. Zhang et al.

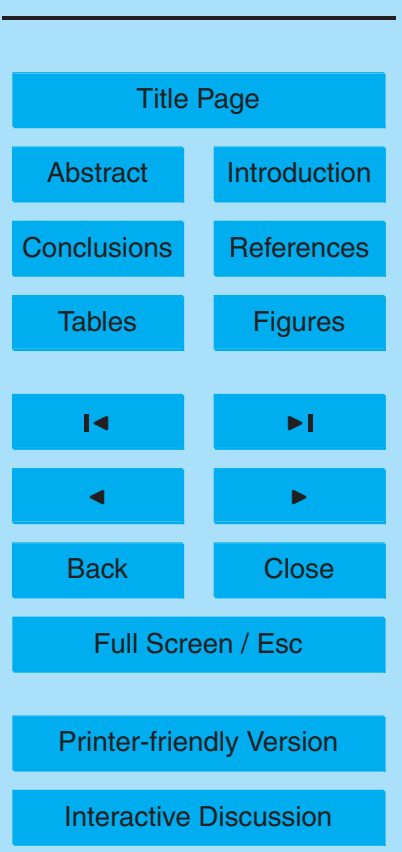


Table 3. The largest enhancement in morning (08:00 a.m.-noon) $\mathrm{O}_{3}$, daily maximum $\mathrm{O}_{3}$, and daily mean $\mathrm{PM}_{2.5}$ in the modeling domain due the additional HONO sources (case HONO S/V subtract case CB05).

\begin{tabular}{rccc}
\hline Date & $\begin{array}{c}\text { The largest } \\
\text { enhancement } \\
\text { in morning } \mathrm{O}_{3} \\
(\mathrm{ppb} \text { V })\end{array}$ & $\begin{array}{c}\text { The largest } \\
\text { enhancement in daily } \\
\text { maximum 8-h } \mathrm{O}_{3} \\
(\mathrm{ppb} \mathrm{V})\end{array}$ & $\begin{array}{c}\text { The largest } \\
\text { enhancement } \\
\text { in daily } \mathrm{PM}_{10} \\
\left(\mu \mathrm{m} \mathrm{m}^{-3}\right)\end{array}$ \\
\hline 22 Oct 2004 & 4 & 4 & 4 \\
23 Oct 2004 & 5 & 4 & 7 \\
24 Oct 2004 & 4 & 3 & 6 \\
25 Oct 2004 & 5 & 3 & 9 \\
26 Oct 2004 & 3 & 3 & 6 \\
27 Oct 2004 & 3 & 3 & 8 \\
28 Oct 2004 & 4 & 5 & 17 \\
29 Oct 2004 & 7 & 7 & 17 \\
30 Oct 2004 & 6 & 6 & 7 \\
31 Oct 2004 & 9 & 7 & 6 \\
1 Nov 2004 & 3 & 5 & 15 \\
\hline
\end{tabular}

\section{ACPD}

$11,15075-15117,2011$

Impact of nitrous acid chemistry on air quality

R. Zhang et al.

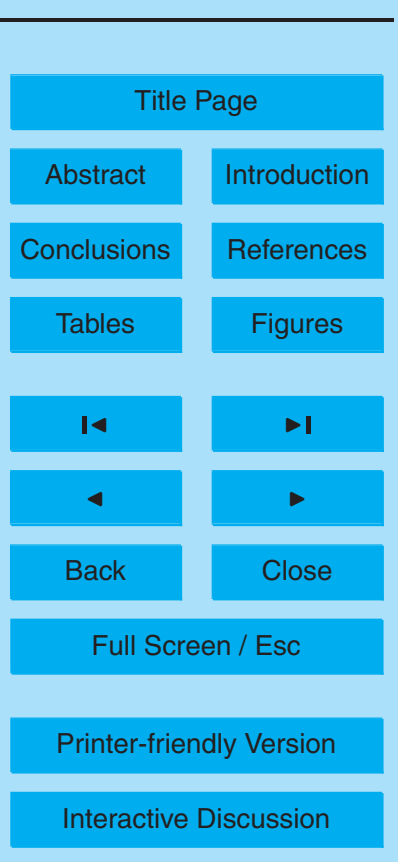

Interactive Discussion 


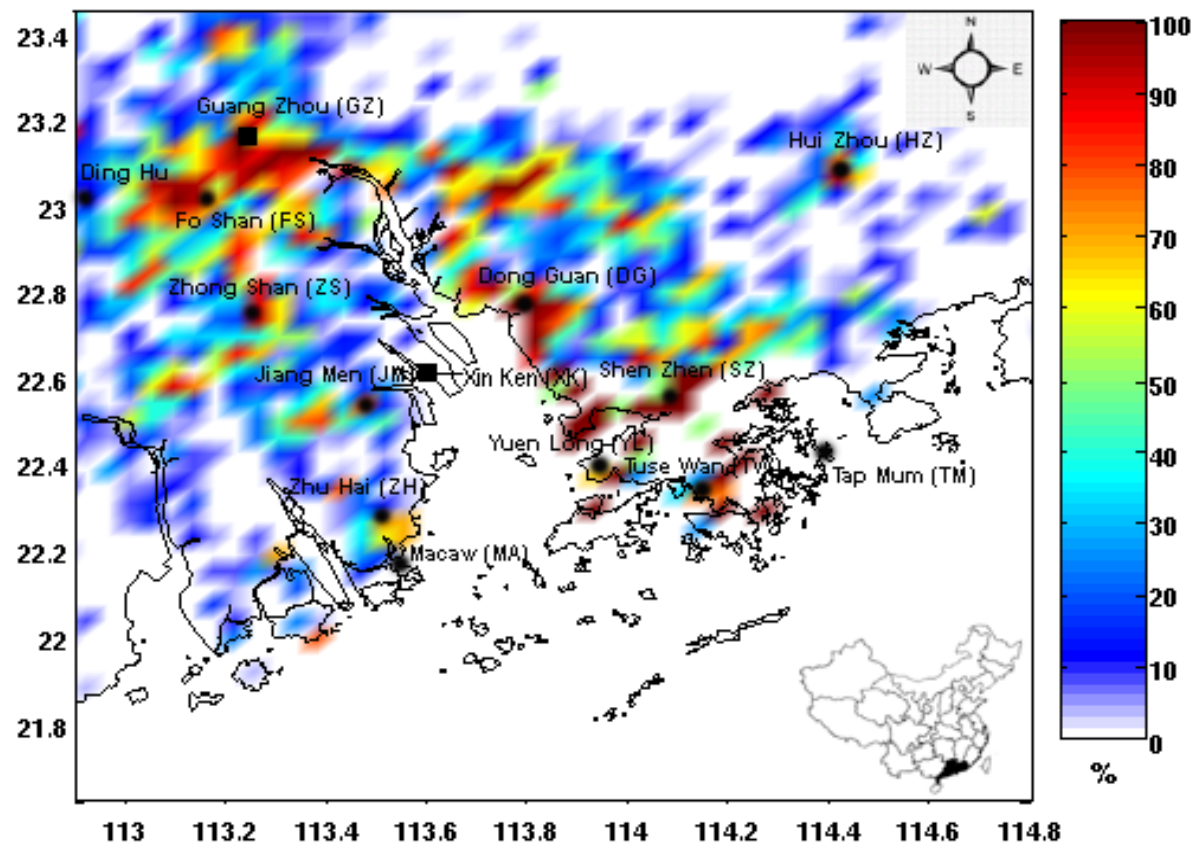

Fig. 1. The geographic coverage of $C M A Q$ model overlapped with urban density fraction (scaled from 0\% to 100\%) over Pearl River Delta region, China. The black dot represents the locations of urban cities over this region, in which the Yuen Long (YL), Tuse Wan (TW) and Tap Mum (TM) are three ambient air quality monitoring stations in Hong Kong with hourly continuous observation data for criteria pollutants.

\section{ACPD}

$11,15075-15117,2011$

Impact of nitrous acid chemistry on air quality

R. Zhang et al.

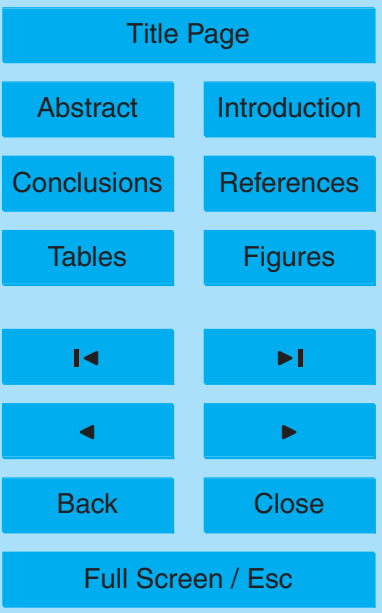

Printer-friendly Version

Interactive Discussion 


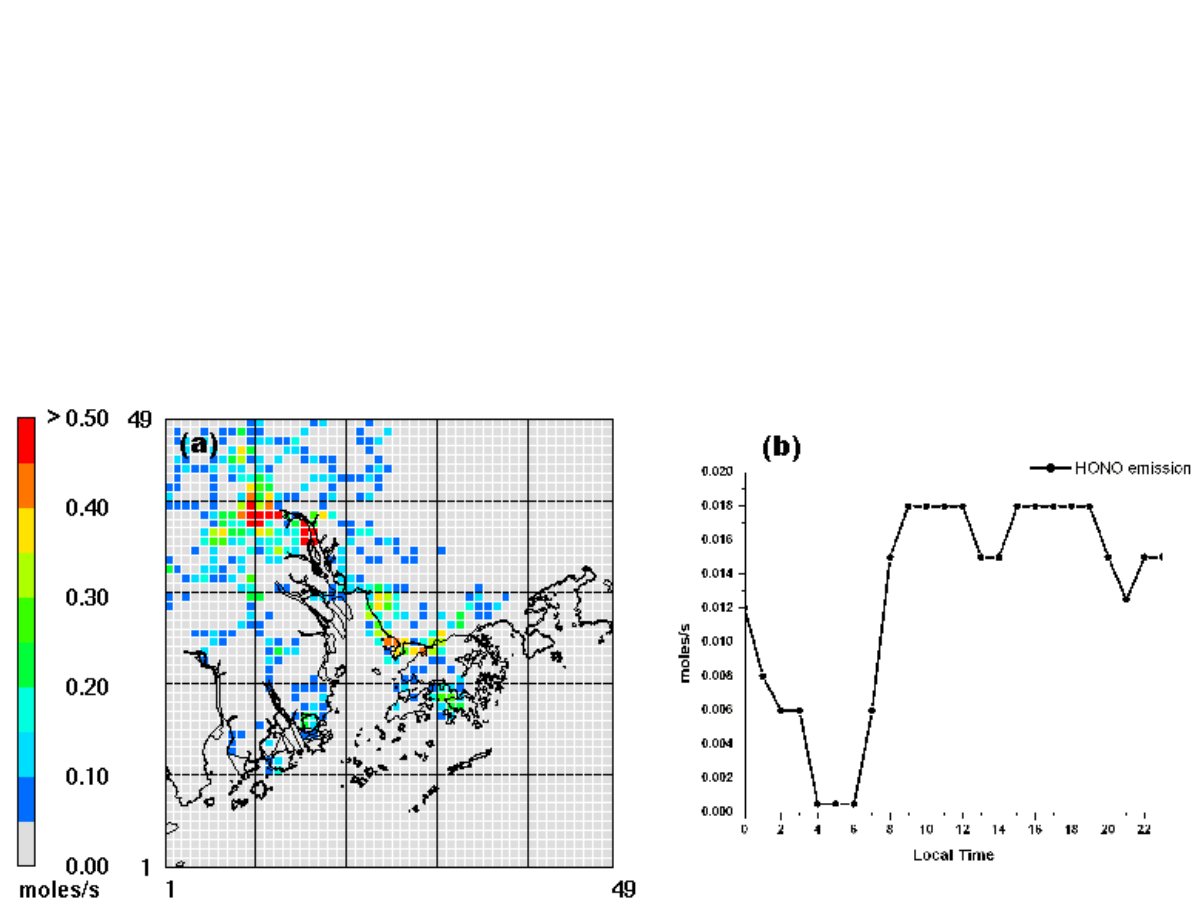

\section{ACPD}

11, 15075-15117, 2011

Impact of nitrous acid chemistry on air quality

R. Zhang et al.

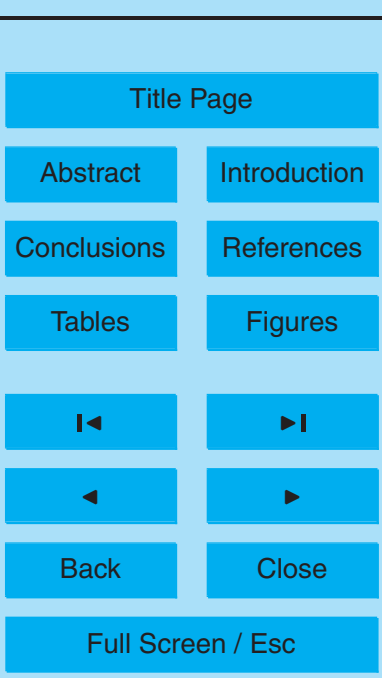

Printer-friendly Version

Interactive Discussion 

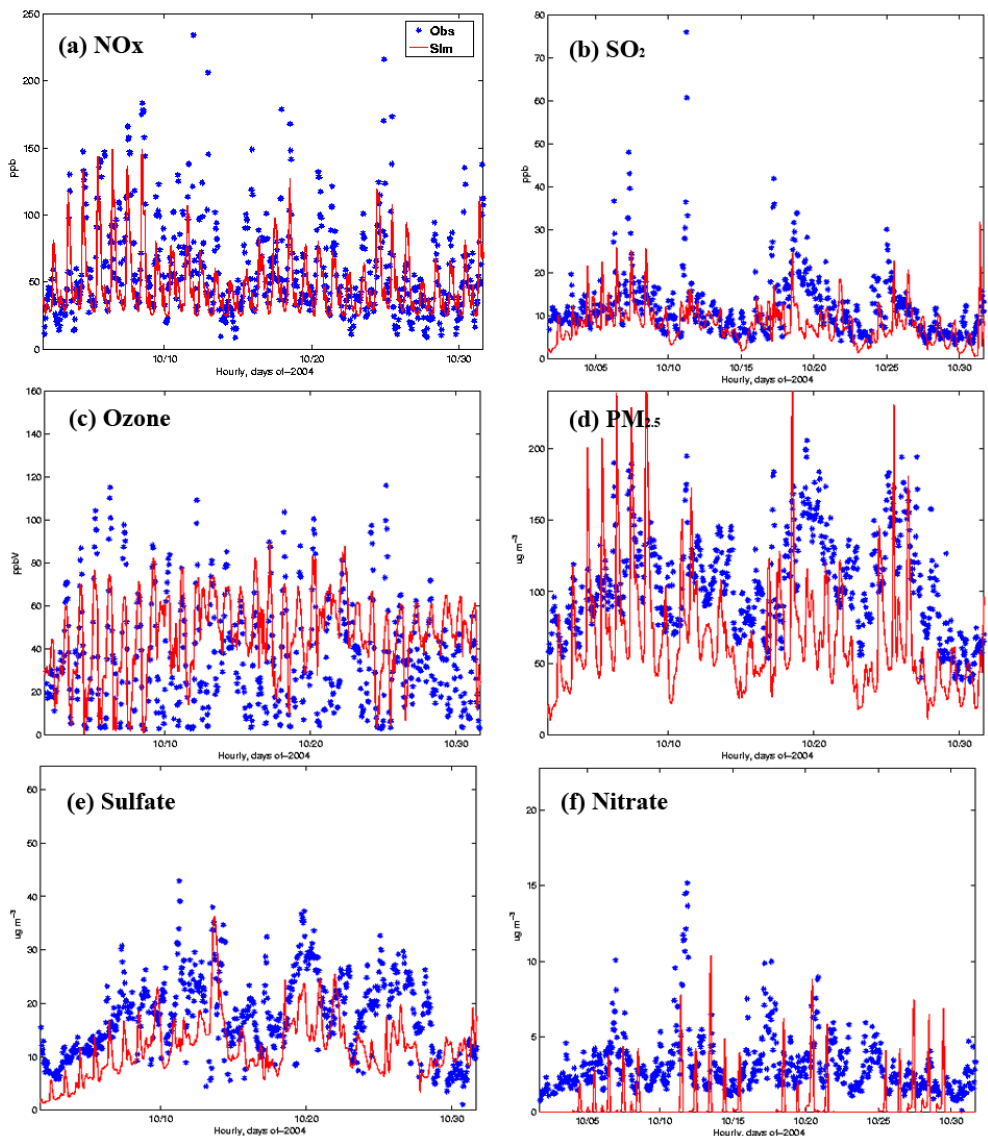

Fig. 3. Comparison of modeled and observed (a) $\mathrm{NO}_{x}$, (b) $\mathrm{SO}_{2}$, (c) $\mathrm{O}_{3}$, (d) $\mathrm{PM}_{10}$, (e) aerosol sulfate, and (f) aerosol nitrate concentration at Yuen Long (YL) station in October 2004. (The blue lines are the EPD observation, while the green lines are the CMAQ model results.)

\section{ACPD}

$11,15075-15117,2011$

Impact of nitrous acid chemistry on air quality

R. Zhang et al.

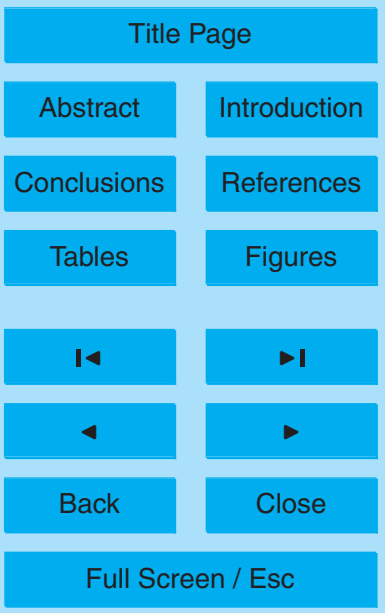

Printer-friendly Version

Interactive Discussion 

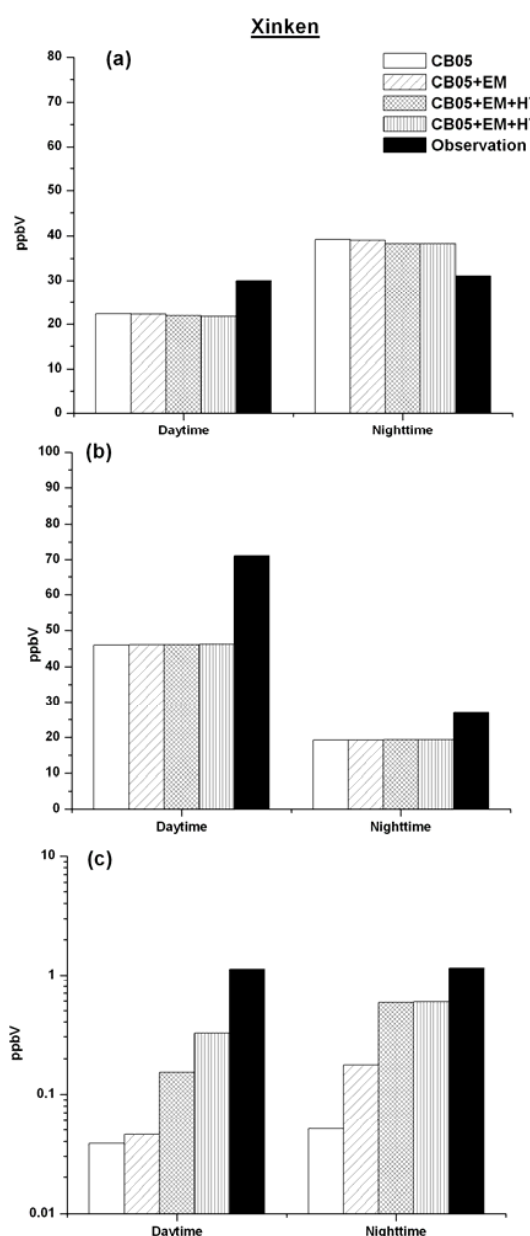
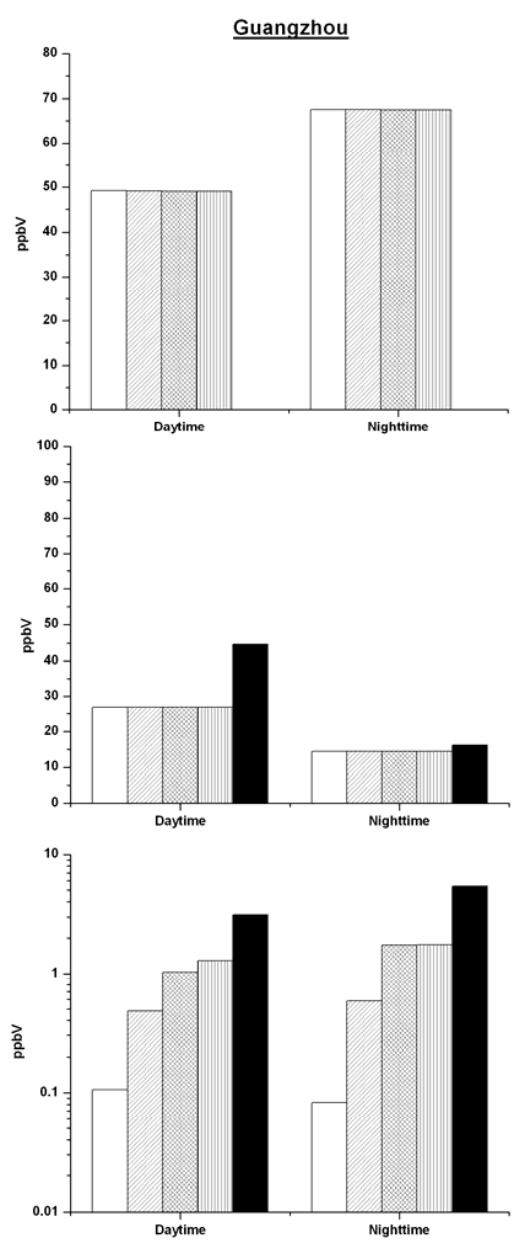

Fig. 4. Model validations after incorporation of different HONO chemistry at Xinken (XK) and Guangzhou (GZ) site for (a) $\mathrm{NO}_{2}$, (b) $\mathrm{O}_{3}$ and (c) HONO simulation.

\section{ACPD}

$11,15075-15117,2011$

Impact of nitrous acid chemistry on air quality

R. Zhang et al.

Title Page

Abstract

Introduction

Conclusions

References

Tables

Figures

14

4

Back

Close

\section{Full Screen / Esc}

Printer-friendly Version

Interactive Discussion 


\section{ACPD}

$11,15075-15117,2011$

Impact of nitrous acid chemistry on air quality

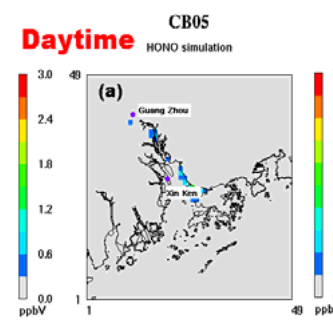

CB05+EM

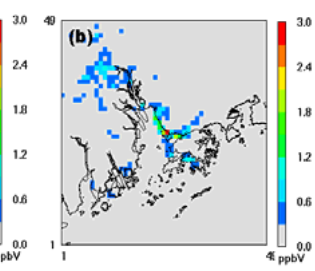

CB05+EM

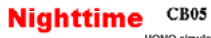

HONO simulation
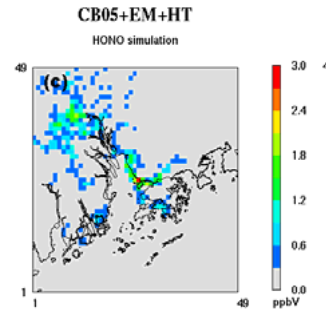

$\mathrm{CB} 05+\mathrm{EM}+\mathrm{HT}+\mathrm{SP}$ HONO simulation
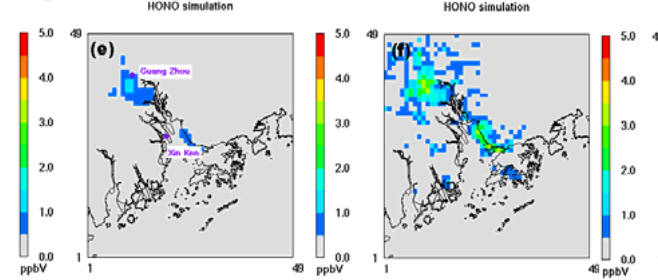

CB05+EM+HT

HONO simulation
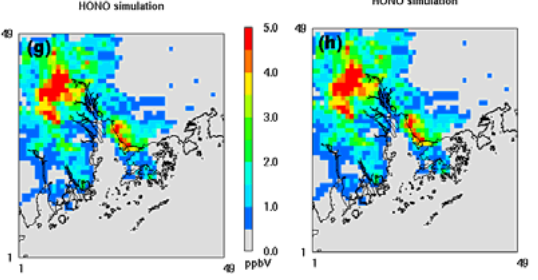

Fig. 5. Spatial distribution of simulated HONO through homogeneous reactions, direct emission, heterogeneous reaction, and surface photolysis formation pathway at daytime (a-d) and nighttime (e-h).

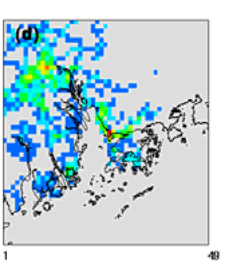

CB05+EM+IIT+SP

R. Zhang et al.

Title Page

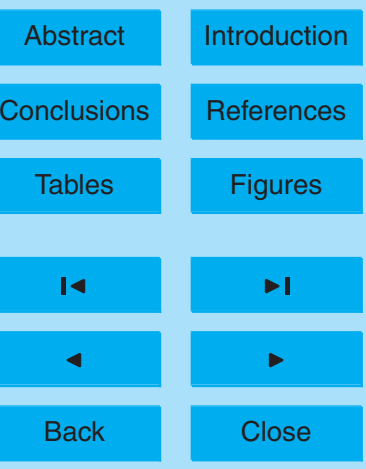

Full Screen / Esc

Printer-friendly Version

Interactive Discussion 
(a)

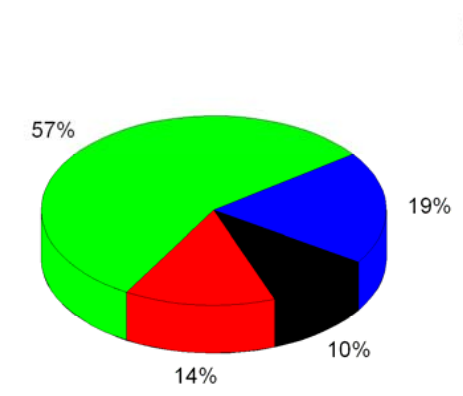

(b)

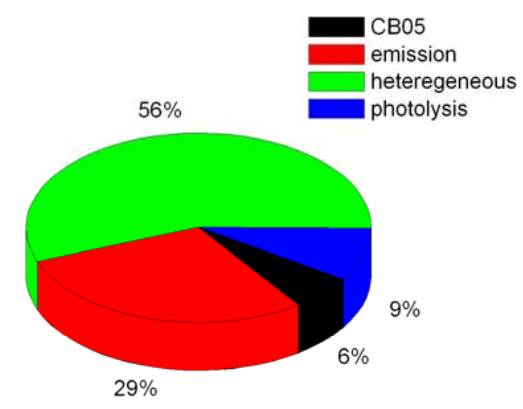

Fig. 6. Average contribution of gas phase (black), direct emission (red), heterogeneous reaction (green) and surface photolysis (blue) source to HONO formation at (a) Xinken and (b) Guangzhou.

\section{ACPD}

$11,15075-15117,2011$

Impact of nitrous acid chemistry on air quality

R. Zhang et al.

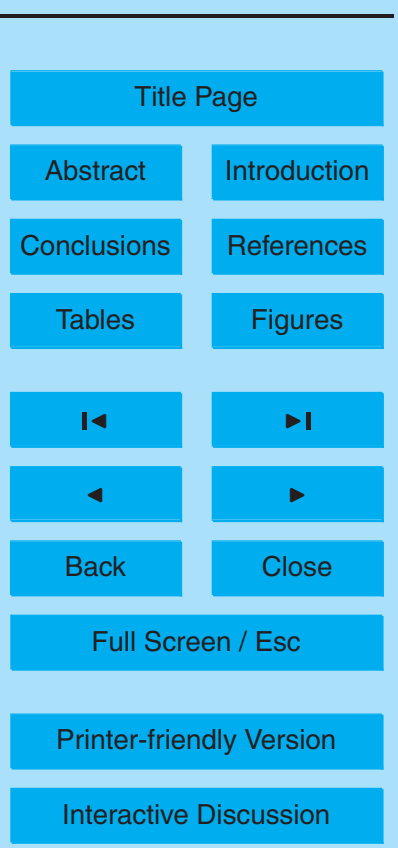

Interactive Discussion 

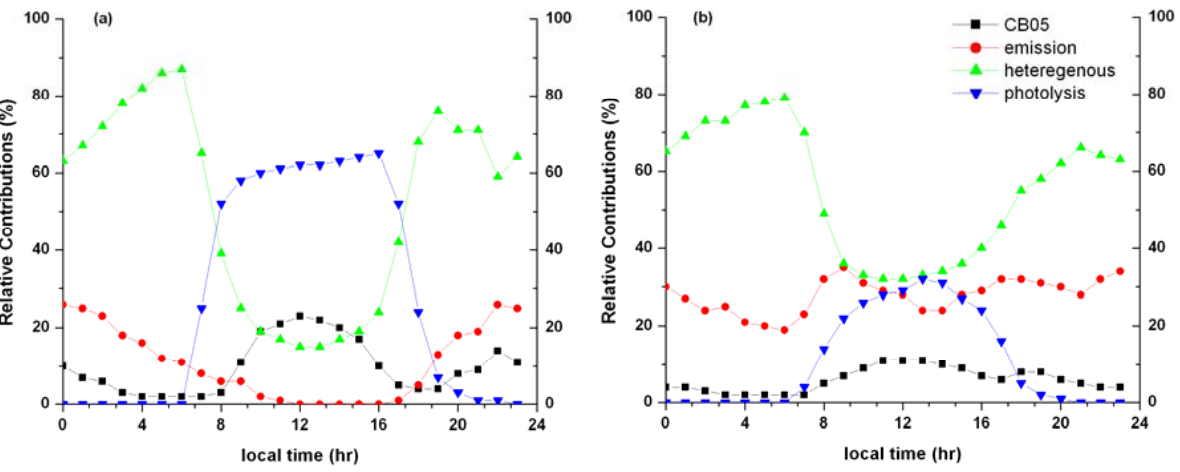

\section{ACPD}

$11,15075-15117,2011$

Impact of nitrous acid chemistry on air quality

R. Zhang et al.

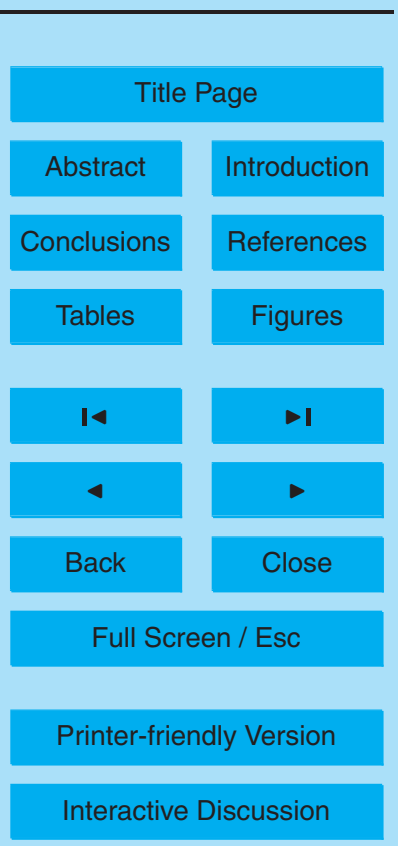

Fig. 7. Average relative contributions of different $\mathrm{HONO}$ sources to predicted $\mathrm{HONO}$ at (a) Xinken and (b) Guangzhou. 

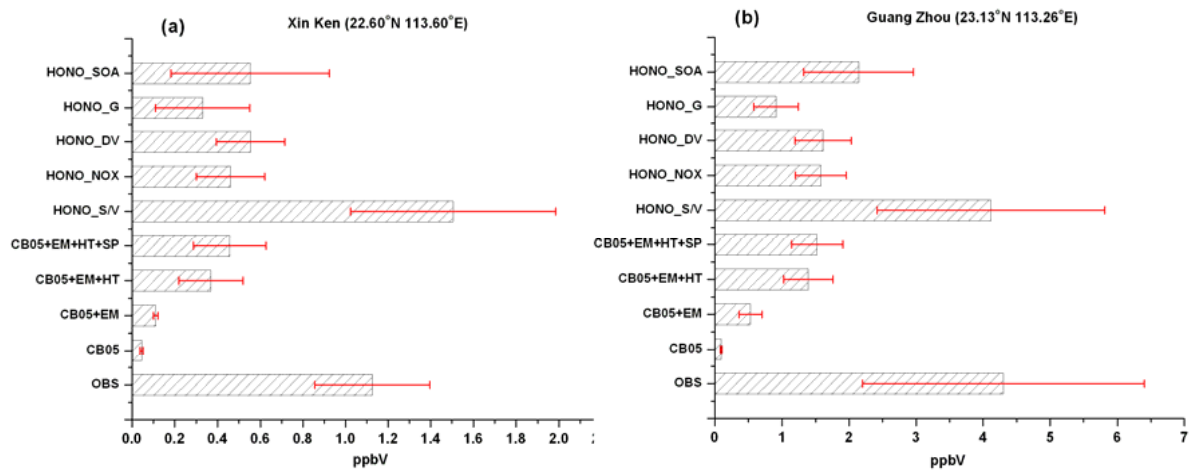

Fig. 8. Simulated mean HONO concentration in (a) Xinken and (b) Guangzhou for different simulation case.

\section{ACPD}

11, 15075-15117, 2011

Impact of nitrous acid chemistry on air quality

R. Zhang et al.

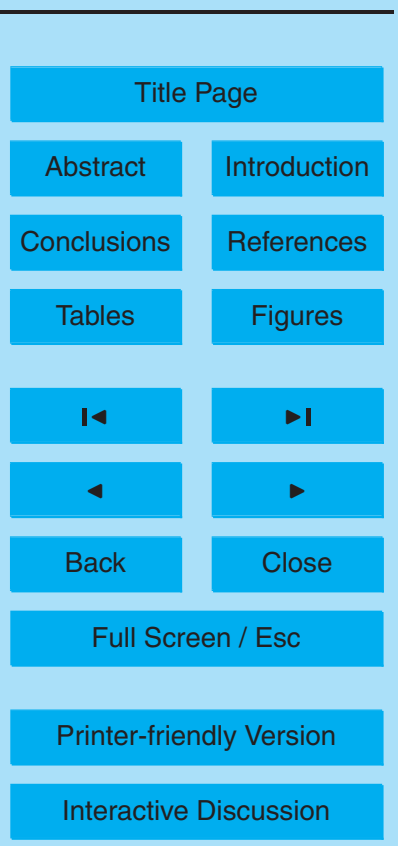



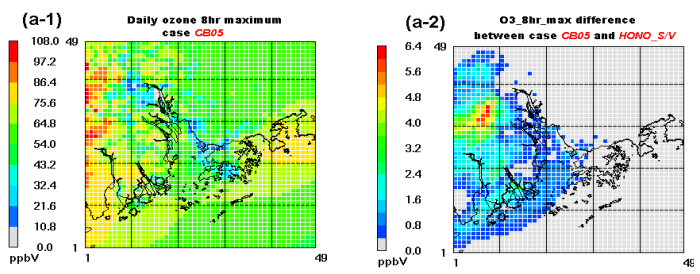

\section{ACPD}

$11,15075-15117,2011$

\section{Impact of nitrous acid chemistry on air quality}
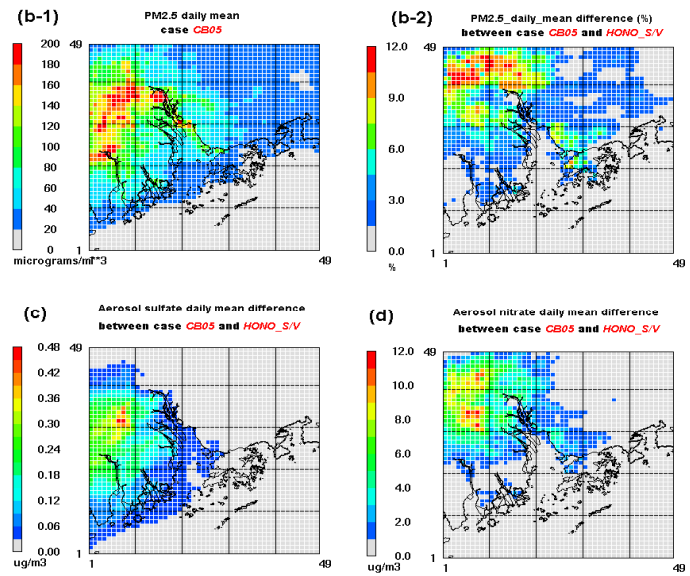

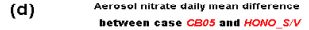
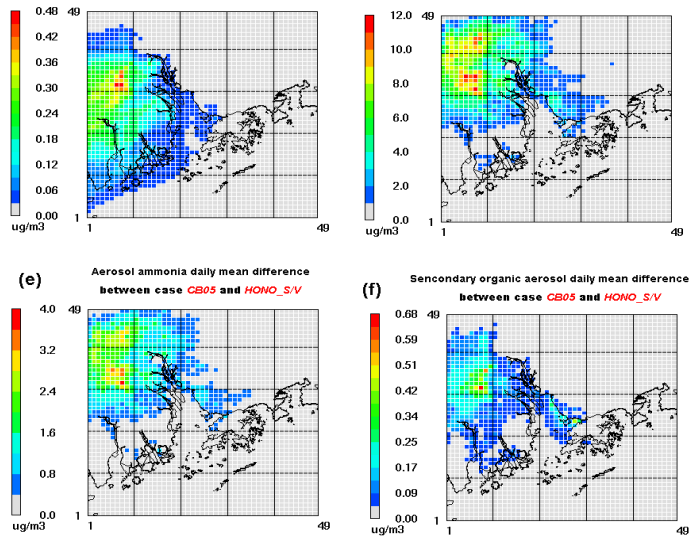

Fig. 9. Spatial distribution of the maximum enhancement due to the HONO chemistry during the entire simulation period for (a) daily $8 \mathrm{~h}$ maximum ozone, (b) daily mean $\mathrm{PM}_{2.5}$, (c) daily mean sulfate, (d) daily mean nitrate, (e) daily mean organic matters, and (f) daily mean SOA.

Title Page

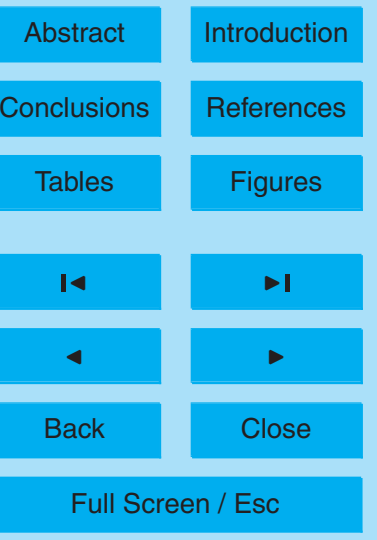

Printer-friendly Version

Interactive Discussion

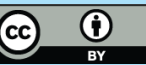




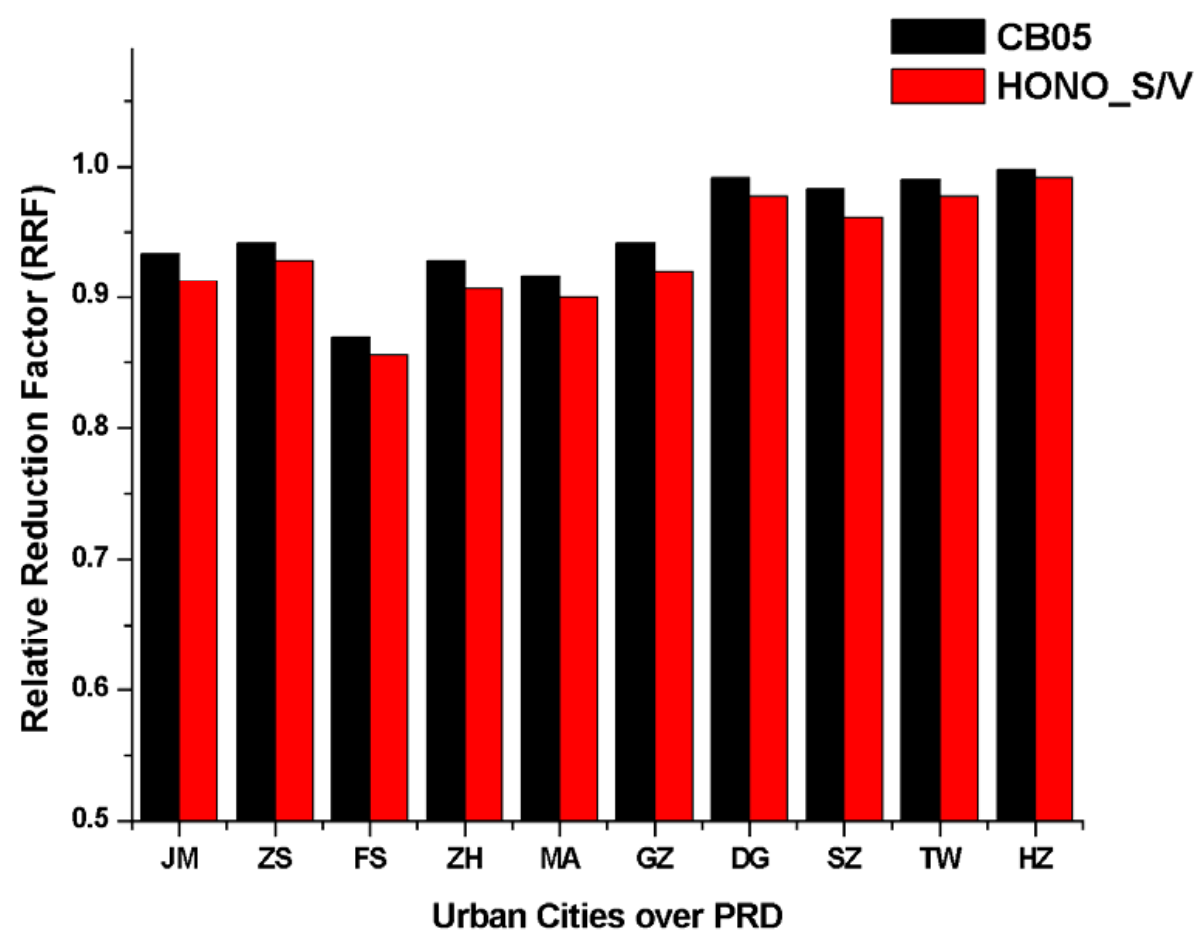

Fig. 10. Average relative reduction factor (RRF) for ozone due to $25 \%$ VOC emission reduction using simulation case CB05 and HONO_S/V. The major cities over PRD are order from by longitude from west to east. JM-Jiangmen, ZS-Zhongshan, FS-Foshan, ZH-Zhuhai, Ma-Macau, GZ-Guangzhou, DG-Dongguan, SZ-Shenzhen, TW-Tusen Wan, HZ-Huizhou.

\section{ACPD}

$11,15075-15117,2011$

Impact of nitrous acid chemistry on air quality

\section{R. Zhang et al.}

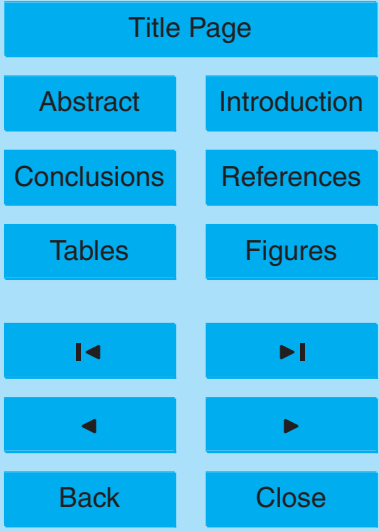

Full Screen / Esc

Printer-friendly Version

Interactive Discussion 